\title{
Diagnosis and management of the drug hypersensitivity reactions in Coronavirus disease 19
}

\author{
aslı gelincik ${ }^{1}$, Knut Brockow ${ }^{2}$, Gulfem Celik ${ }^{3}$, Inmaculada Doña ${ }^{4}$, Cristobalina Mayorga ${ }^{5}$, \\ A Romano ${ }^{6}$, Ozge Soyer ${ }^{7}$, Marina Atanasković-Marković ${ }^{8}$, Annick BARBAUD ${ }^{9}$, and Maria \\ Torres $^{10}$ \\ ${ }^{1}$ Istanbul University, Istanbul Faculty of Medicine \\ ${ }^{2}$ Technical University of Munich \\ ${ }^{3}$ Ankara University School of Medicine \\ ${ }^{4}$ Carlos Haya Hospital \\ ${ }^{5}$ IBIMA-Regional University Hospital of Malaga \\ ${ }^{6}$ Presidio Columbus \\ ${ }^{7}$ Hacettepe University, School of Medicine \\ ${ }^{8}$ University of Belgrade, Facuty of Medicine \\ ${ }^{9}$ Sorbonne Universités, UPMC Univ Paris 06 \\ ${ }^{10}$ Regional University Hospital of Malaga-IBIMA-UMA-BIONAND-ARADyAL
}

May 8, 2020

\begin{abstract}
Coronavirus disease 2019 (COVID-19), a respiratory tract infection caused by a novel human coronavirus, the severe acute respiratory syndrome coronavirus 2 , leads to a wide spectrum of clinical manifestations ranging from asymptomatic cases to patients with mild and severe symptoms, with or without pneumonia. Given the huge influence caused by the overwhelming COVID-19 pandemic affecting over three million people worldwide, a wide spectrum of drugs is considered for the treatment in the concept of repurposing and off-label use. There is no knowledge about the diagnosis and clinical management of the drug hypersensitivity reactions that can potentially occur during the disease. This review brings together all the published information about the diagnosis and management of drug hypersensitivity reactions due to current and candidate off-label drugs and highlights relevant recommendations. Furthermore, it gathers all the dermatologic manifestations reported during the disease for guiding the clinicians to establish a better differential diagnosis of drug hypersensitivity reactions in the course of the disease.
\end{abstract}

\section{INTRODUCTION}

Coronavirus disease 2019 (COVID-19) is a respiratory tract infection caused by a novel member of human coronavirus, the severe acute respiratory syndrome coronavirus 2 (SARS-CoV-2) (1). It causes a wide spectrum of clinical manifestations ranging from asymptomatic cases to patients with mild, uncomplicated illness and severe cases, with or without pneumonia (2). Hospitalization and oxygen support, and admission to an intensive care unit are required in $14 \%$ and $5 \%$ of the patients, respectively (1). Gastrointestinal symptoms and positive viral nucleic acid testing on rectal swabs are considered as indicators of infection in digestive system and fecal-oral transmission of COVID-19 (3). Moreover, skin symptoms, including exanthems, may appear during the evolution of the disease leading to differential diagnosis with drug hypersensitivity reactions (DHRs) (4). 
In critically ill patients, COVID-19 can be complicated by acute respiratory distress syndrome (ARDS), septic shock, and multi-organ dysfunction syndrome (1). In such patients, in response to viral infection, the excessive activation and expansion of $\mathrm{T}$ lymphocytes and macrophages lead to an overproduction of cytokines, which causes a cytokine storm and a hyperinflammatory state $(5,6)$. Acute hyperinflammation may activate coagulation cascade and inhibit fibrinolytic reaction, thus promoting thrombosis. Coagulopathy and thrombocytopenia are serious complications which increase the risk of haemorrhage and thrombosis and progress to disseminated intravascular coagulation (DIC) (7).

The periodically updated World Health Organisation interim guidance allows reliable comparison of investigational therapeutic interventions as part of randomized controlled trials, provides recommendations for the management and forms the basis of many institutional or national protocols (1). Unfortunately, none of the drugs used for COVID-19 have been proven to be truly effective yet; besides, no specific antiviral drugs have been approved for COVID-19 by health authorities $(8,9)$. At the moment, there is no specific treatment for COVID-19, and standard practice of care focuses on treating the clinical symptoms with supportive care (1).

In this review, diagnosis and management of DHRs, which are expected to be caused by current or candidate repurposed and off-label drugs used for COVID-19 treatment mostly based on prior knowledge, are discussed $(8,10,11)$. Drugs in this review are classified into four groups according to their potential roles in different phases of the disease as antiviral drugs, antiviral and/or immunomodulatory drugs used in viral pneumonia; anti-cytokine and anti-inflammatory drugs considered during macrophage activation syndrome (MAS) and cytokine storm; anti-inflammatory drugs in ARDS; and anti-aggregant and anti-coagulant drugs in coagulopathy (Figure 1). Information of DHRs due to the use of additional drugs for various purposes can be found in the relevant European Academy of Allergy and Clinical Immunology (EAACI) resources $(12-20)$.

Since emerging recent findings are dynamically changing the clinical interventions, it is expected that the list of drugs determined according to current knowledge may change with upcoming recommendations in future.

\section{SKIN MANIFESTATIONS INDUCED BY COVID-19}

There have been increasing reports of dermatologic manifestations associated with COVID-19 (Table 1). It is knowledge, although in progress, rapidly evolving as evidenced by most publications being ahead of print and available only in an electronic version or reported in networks.

According to pathogenetic mechanisms, skin manifestations reported so far can be divided into 1. Skin manifestations similar to those in other viral infections, and 2. Skin manifestations related to thrombovascular events and vascular pathologies.

\section{Skin manifestations similar to those in other viral infections}

During the COVID-19 outbreak in China, it was not a focus to document skin manifestations. Consequently, skin rash has only been reported in 2 out of 1.099 infected patients $(0.2 \%)(21)$. In contrast, a study by dermatologists from Italy reported skin manifestations in 18/88 patients (20.4\%) with COVID-19 (4). Cutaneous manifestations seen were either erythematous rash $(n=14)$, widespread urticaria $(n=3)$, or chickenpox-like vesicular rash $(\mathrm{n}=1)$. In Spain, among 375 patients with suspected or confirmed COVID-19, maculopapular eruptions (MPEs), sometimes similar to pityriasis rosea, were observed in $47 \%$ of the cases, urticarial lesions in 19\% and vesicular eruptions of the trunk in 9\% (22). Another case of urticaria was presented in France (Figure 2A)(23) and patients with morbilliform exanthem in the USA (Figure 2B)(24). Varicella-like lesions predominantly on the trunk were described in 22 patients with proven COVID-19 infection in Italy (25). Predominance of vesicles was reported in $54.5 \%$ and generally mild itching in nine $(40.9 \%)$ patients. The vesiculopapular exanthem appears to develop early in the course of the disease (Figure 2C $(26))(22,26)$. Two patients with bilateral flexural exanthems resembling systemic drug-related intertriginous exanthems (SDRIFE), one with axillary purpuric lesions associated with thrombocytopenia, have been published (Figure 2D) (27). A prospective study from France reported a prevalence of 5/103 (4.9\%) and confirmed association of pruritic erythematous rash $(\mathrm{n}=2)$ and urticaria $(\mathrm{n}=2)$ with COVID-19 infections (28); they additionally 
observed one oral herpes simplex virus type 1 reactivation. The histopathological picture of exanthematic skin lesions generally resembles that of viral exanthems. However, in individual patients, early microthrombi and an interface dermatitis with necrotic keratinocytes surrounded by lymphocytes have been reported (29).

\section{Skin manifestations associated with thrombovascular events and vascular pathologies}

COVID-19 exanthems have also been reported with petechiae and low platelet count resembling dengue (30). In two patients, unilateral lesions on the thigh resembling livedo reticularis or erythema ab igne have been described with microthromboses discussed as possible etiology (Figure 3A) (31).

Chilblain-like skin lesions have been frequently reported to be associated with COVID-19 $(22,32,33,34)$ (Figure 3B(32)). They appear in up to $19 \%$ of patients, typically in mildly affected ones, and late in the evolution of the disease $(22,34)$. Vesicles, pustules and erosions on these violaceous plaques may occur (34). In Spain they were observed in $19 \%$ of 375 cases (22).

Seven patients had cutaneous acro-ischemia including finger and toe cyanosis, skin bulla and dry gangrene associated with COVID-19 infection-induced hypercoagulation including definitive DIC in four patients. Five of these patients finally died (Figure 3C)(35). A catastrophic microvascular injury syndrome mediated by activation of complement pathways and an associated procoagulant state were described in severe COVID-19 with purpuric skin rash in $3 / 5$ patients $(36)$.

In conclusion, the prevalence of cutaneous manifestations in COVID-19 patients has been reported between $0.2 \%, 4.9 \%$ and $20.9 \%(4,21,27)$. Most skin manifestations resemble cutaneous involvement commonly occurring during viral infections, i.e. erythematous rash and acute urticaria. Drug exanthems have to be considered as differential diagnosis (15). Vesicular varicella-like exanthems may be more specific for COVID-19. Flexural distribution, and petechia as well as erythema ab igne-like lesions have been described. Violaceous, infiltrated painful plaques resembling chilblains have been frequently reported and discussed as typical manifestations. Necrotic lesions occurred in older and in severely ill patients with increased mortality (22). Cutaneous acro-ischemic microthromboses and small blood vessel occlusion have to be further explored for their causality and specificity for COVID-19 manifestations.

\section{ANTI-VIRAL AGENTS USED FOR VIRAL PNEUMONIA}

\section{Clinical use in COVID-19}

Most antiviral agents used for COVID-19 act either by inhibiting RNA-dependent RNA polymerase (remdesivir (GS-5734)) or proteases (lopinavir/ritonavir (LPV/r), favipiravir (FPV), ribavirin and darunavir) (3740). Additionally, umifenovir plays a role in viral entry by inhibiting the hemagglutinin-mediated membrane fusion, and oseltamivir is a neuraminidase inhibitor which blocks the release of viral particles from the host cells in influenza infection (41). Remdesivir and FPV are considered to be the most effective agents and are mostly used in combination with other COVID-19 medications like hydroxychloroquine (37-40). Oseltamivir is recommended for concomitant influenza infection (42). Darunavir or LPV/r can be concomitantly administered with chloroquine or hydroxychloroquine (40).

\section{Hypersensitivity reactions}

DHRs to ribavirin, darunavir, LPV/r, remdesivir, and oseltamivir are rarely reported whereas no DHRs to favipiravir and umifenovir are known at present (43-48).

Ribavirin

Ribavirin is used in combination with pegylated-interferon $\alpha 2 \mathrm{a}$ (peg-IFN- $\alpha 2 \mathrm{a}$ ) for treating chronic hepatitis $\mathrm{C}$, and both have been associated with several cutaneous DHRs (49). Ribavirin alone causes dermatitis, alopecia, and photoallergic eczematous reactions (50,51), and the risk of DHR increases with combination therapy: rash [response rate (RR,1.74; 95\% confidence interval (CI) 1.17-2.6), dermatitis (RR, 1.67; 95\% CI, 1.21-2.30), and pruritus (RR, 1.62; 95\% CI,1.29-2.02) (52). A meta-analysis revealed that, on combination therapy, mild to moderate cutaneous reactions appear in $13.3 \%$ of patients, localized cutaneous reactions in 
$2.6 \%$, generalized reactions-pruritus, skin xerosis and eczematous changes in $10.3 \%$, alopecia in $4.1 \%$, and exacerbation of lichen planus in less than $1 \%$ (43).

The etiological diagnosis is difficult in case of combination therapy. A drug provocation test (DPT) confirmed the diagnosis of ribavirin hypersensitivity in a patient having MPE due to combined use of peg-IFN- $\alpha 2 \mathrm{a}$ and ribavirin (53). In another case, an erythema multiforme type drug eruption occurred with peg-IFN- $\alpha 2 \mathrm{a}$, ribavirin and/or fluvastatin sodium therapy and a positive lymphocyte transformation test (LTT) confirmed the diagnosis of ribavirin hypersensitivity (54). Successful desensitization protocols were reported $(55,56)$.

Lopinavir/ritonavir (LPV/r)

$\mathrm{LPV} / \mathrm{r}$, either alone or in combination, has been rarely reported to be associated with DHRs. In human immunodeficiency virus (HIV) infected patients who received LPV/r combination, MPE rate was reported as 2-4\% (57). Acute Generalized Exanthematous Pustulosis (AGEP) was described in two cases receiving $\mathrm{LPV} / \mathrm{r}(58)$.

In a multicentre randomized study that evaluated the long-term efficacy and safety of the combination of efavirenz or $\mathrm{LPV} / \mathrm{r}$ plus abacavir/lamivudine, $2 / 63$ patients in the LPV/r group discontinued the study because of a DHR (59).

In a recent cohort of 199 severe COVID-19 patients who received LPV/r combination, only two (1\%) experienced self-limited skin eruptions (44). A recent study evaluating 217 patients from China revealed that most of the adverse drug reactions (ADRs) were associated with LPV/r and umifenovir with $63.8 \%$ and $18.1 \%$ respectively and history of a drug allergy was higher in these patients (8.5\%) comparing with the ones without ADRs $(2.2 \%$ vs., $P<0.044)(60)$.

Darunavir

Darunavir can induce a variety of delayed skin eruptions from mild MPE in most cases, to severe bullous cutaneous reactions in HIV infected patients $(45,61)$. A phase III randomized clinical trial performed in 604 patients treated with darunavir/r or LPV/r showed that the percentage of patients experiencing rash was higher in those receiving darunavir/r compared with others (16\% vs $7 \%$ ). Two patients receiving darunavir $/ \mathrm{r}$ required treatment cessation due to a severe rash (45). Darunavir contains a sulfonamide moiety and should be used with caution in patients with a known sulfonamide allergy (62). Desensitization was reported to be successful in patients with non-immediate hypersensitivity reactions (NIHRs) to darunavir $(63,64)$.

Oseltamivir

Oseltamivir, used in influenza, causes rare hypersensitivity reactions although close monitoring of patients is important as 2 cases with Stevens-Johnson syndrome (SJS)/Toxic epidermal necrolysis (TEN) have been reported $(46,47)$, with only one being confirmed by LTT $(47)$. Another case report revealed anaphylaxis due to oseltamivir confirmed by a skin prick test (SPT) (65).

Remdesivir

A recent multicentre study showed that only one (1.6\%) out of 61 patients with COVID-19, experienced MPE during remdesivir treatment and therefore discontinued it prematurely (48).

\section{ANTIVIRAL AND/OR IMMUNOMODULATORY DRUGS USED FOR VIRAL PNEUMO- NIA}

Azithromycin

\section{Clinical use in COVID-19}

Azithromycin interferes with virus internalization process in influenza infection (66) and has shown clinical effects in COVID-19 patients, although its mechanism against SARS-CoV-2 remains unclear (67).

\section{Hypersensitivity reactions}


Regarding immediate hypersensitivity reactions (IHRs), urticaria is the most frequent manifestation (68); furthermore, anaphylaxis can occur (69). Concerning NIHRs, MPE is described to occur independently (70) or only in presence of a concurrent infection (71). Azithromycin has been implicated in contact dermatitis in occupational (72) and non-occupational settings (73). Cases of fixed drug eruption (FDE) (74), AGEP (75) and Drug Reaction with Eosinophilia and Systemic Symptoms (DRESS) (76), SJS (77,78), leukocytoclastic vasculitis (79), and hypersensitivity myocarditis (80) were reported.

Diagnosis is complex as skin testing is not validated, presenting discrepancies in non-irritating dilutions for SPT and intradermal test (IDT) (81,82). For NIHRs, positive responses to patch tests (PTs) were described (72). In addition, no validatedin vitro tests are available (83). Oral DPT remains as the gold standard for diagnosis (84). A successful desensitization protocol was reported in a case of mast cell activation syndrome (85).

Hydroxychloroquine / Chloroquine

\section{Clinical use in COVID-19}

Hydroxychloroquine/chloroquine have in vitro antiviral effects against SARS-Cov2 by preventing virus/cell fusion, and immunomodulatory effects by inhibiting production of inflammatory cytokines (86).

\section{Hypersensitivity reactions}

Dermatologic ADRs are difficult to be distinguished as a side effect of or an allergic reaction to these drugs or a flare of the underlying dermatological disease $(87,88)$. The most common manifestation is mild pruritic MPEs within initial 4 weeks of treatment (87). High association with AGEP [OR: 39 (8-191)] was described (89). Cases of DRESS (90,91), pustular DRESS (92), erythema multiforme (93), bullous erythema (94), SJS/TEN (95-97), photoallergic dermatitis (98), and occupational contact dermatitis (99) have been reported.

PTs are reported to be useful for the diagnosis of NIHRs $(93,95,100)$, confirming a T-cell mediated mechanism. However, in a series of 14 patients with ADRs due to chloroquine/hydroxychloroquine, skin tests (STs) were negative in all cases (87). DPT is useful in non-severe cutaneous ADRs in order to differentiate allergic reactions from dermatological adverse effects since only $30 \%$ of the patients reporting cutaneous ADRs reveal a positive DPT (87). Successful desensitization protocols of hydroxychloroquine in MPE were reported (101-104). Recently, a 5-hour desensitization protocol for non-immediate urticaria was successfully administered (105).

Two cases of IHR were reported $(106,107)$ and one was confirmed by SPTs $(106)$, however there are no available data for in vitro diagnosis. A hydroxychloroquine desensitization procedure that enables the turning of positive SPTs into negative was published (106). In a case of anaphylaxis a 7 day-desensitization procedure was successfully performed with premedication (107).

Auranofin

\section{Clinical use in COVID-19}

Auranofin is an anti-inflammatory compound that can possibly inhibit the replication of SARS-CoV-2 in cell culture and reduce the expression of cytokines caused by SARS-CoV-2 and the associated lung damage (108).

\section{Hypersensitivity reactions}

There are no reported hypersensitivity reactions due to auranofin.

Interferons

Clinical use in COVID-19 
Type I IFNs (IFN- $\alpha$ and IFN- $\beta$ ) can inhibit the replication of both SARS and Middle East respiratory syndrome coronavirus (MERS-CoV) and are recommended in combined therapies with other antiviral agents $(109,110)$.

\section{Hypersensitivity reactions}

Cutaneous eruptions induced by IFNs are common, with an incidence of 13-23\% (111,112). Localized reactions at injection sites are most frequent at 48 weeks (113). Diffuse skin symptoms including urticaria, generalized eczema, papules are common and mostly treated with symptomatic treatment $(111,114,115)$. Among 26 patients with non-immediate reactions to IFNs, 12 cases reported generalized eczema, 10 MPE, 3 generalized urticaria and 1 lichenoid eruption (116). Cases of FDEs (117), and subacute cutaneous lupus (118) were described.

There are few case reports of immediate urticaria $(119,120)$ and anaphylaxis $(121,122)$. For IHRs to IFN$\beta$, positive STs were reported $(119,121)$. For NIHRs, PTs have a low value and are not recommended, whereas delayed reading IDTs are useful $(116,123)$. A positive DPT was reported in a patient experiencing anaphylaxis due to peg-INF- $\alpha 2 a$ with negative STs (122). Successful desensitization protocols both for IHRs $(120)$ and NIHRs $(116,124)$ due to different IFNs were reported.

Ivermectin

\section{Clinical use in COVID-19}

Ivermectin is an anti-parasitic drug also shown to have an in vitro activity against SARS-CoV-2 by inhibition of viral replication (125).

\section{Hypersensitivity reactions}

Rare case reports of multiple FDEs (126), confirmed DRESS by skin biopsy and blood eosinophilia (127), confirmed SJS (128) and TEN (129) by skin biopsy were published. No data about STs, in vitro tests or DPT are available. In addition, no cases of desensitization were reported.

Nitazoxanide

\section{Clinical use in COVID-19}

Nitazoxanide is an antiparasitic agent which also has antiviral activities. Combined with hydroxychloroquine or azithromycin, a synergistic effect has been suggested as hydroxychloroquine and azithromycin inhibit viral entry and fusion, while nitazoxanide upregulates innate immune response to prevent on-going viral replication in COVID-19 (130).

\section{Hypersensitivity reactions}

No DHRs to nitazoxanide are reported.

\section{ANTI-CYTOKINE/ANTI-INFLAMMATORY DRUGS USED FOR MAS/CYTOKINE STORM/ARDS}

Tocilizumab

\section{Clinical use in COVID-19}

Tocilizumab, an anti-IL-6 receptor humanized monoclonal antibody, is under investigation for treatment of COVID-19 and has shown promising results in cytokine storm (6).

\section{Hypersensitivity reactions}

The rate of all ADRs to tocilizumab is reported to be around 8\%, among them 0.1-0.7\% are DHRs (131). DHRs to tocilizumab are both NIHRs $(132,133)$ and IHRs (134-137). In an adult cohort the incidence of IHRs was reported as 5.5\% (136) whereas in a paediatric cohort it was $13.6 \%$ (134). 
Regarding NIHRs, cases of non-immediate urticaria (138), DRESS (139,140), SJS (141), and AGEP (142) were reported. Younger age, shorter stature, lighter weight, and increased disease activity in the early period of tocilizumab administration have been identified as risk factors for DHRs (143).

Although not standardized, DPTs, SPTs and IDTs were used for diagnosis of IHRs in case reports $(134,136)$. Only one study revealed that STs have a low negative predictive value in NIHR (137).Desensitization to tocilizumab in NIHRs was effectively applied in a weekly scheme with premedication in one case (138). Rapid drug desensitization is successfully and routinely used for IHRs $(19,131)$.

Anakinra

\section{Clinical use in COVID-19}

Anakinra, a recombinant IL-1 receptor antagonist, is under investigation for the treatment of cytokine storm seen during COVID-19 (5).

\section{Hypersensitivity reactions}

Anakinra causes ADRs in $75 \%$ of patients. Many of them are related to injection site reactions within the first weeks of application and can present either as an IHR or NIHR $(144,145)$. Systemic IHRs such as urticaria, angioedema, anaphylaxis (146-148), and NIHRs (149) as infiltrating erythematous skin plaques were rarely reported as single cases. IHR after a first dose of anakinra was reported in a case possibly due to components that are able to induce a direct mast cell degranulation $(148,150)$.

For evaluating IHRs to anakinra, SPTs, and IDTs were performed with the undiluted drug $(147,148)$. Both for IHRs $(146,148)$ and NIHRs $(149)$, successful desensitization protocols were reported.

Sarilumab

\section{Clinical use in COVID-19}

Sarilumab, another IL-6 receptor antagonist, is under investigation in a phase II/III clinical trial in patients with severe COVID-19 infection (151).

\section{Hypersensitivity reactions}

It is generally a well-tolerated drug; however, it can cause local reactions on injection site. In an open-label study, in $3 \%$ of the patients it caused a pruritic generalized rash which did not affect the treatment (152).

Canakinumab

\section{Clinical use in COVID-19}

Canakinumab, a high-affinity human anti-IL-1 $\beta$ monoclonal antibody, is considered as a candidate in treatment of severe COVID-19 (153).

\section{Hypersensitivity reactions}

This anti-IL-1 agent is normally well tolerated and indicated as an alternative in cases with an anaphylactic reaction to anakinra (135). However, there is a recently reported case who developed immediate diffuse urticaria after the tenth canakinumab administration and was prevented from further reactions with cetirizine premedication (134).

Janus kinase (JAK) inhibitors (Baricitinib, Ruxolitinib, Tofacitinib)

\section{Clinical use in COVID-19}

JAK-inhibitors are under investigation for their potential role in regulating the overactive signalling in the JAK-STAT pathway seen during cytokine storm in critically ill COVID-19 patients. Baricitinib with its potential to inhibit clathrin-mediated endocytosis and its ability to ameliorate associated chronic inflammation in interferonopathies is expected to show promising results in ongoing clinical trials of COVID-19 (154,155). 


\section{Hypersensitivity reactions}

Few cases were reported: one with a morbiliform eruption and exfoliative dermatitis due to ruxolitinib (156), another one with palmoplantar pustulosis due to baricitinib (157), and cases of acute urticaria (158) and palmoplantar pustulosis (159) due to tofacitinib.

Cyclosporine

\section{Clinical use in COVID-19}

Cyclosporine A prevents the transcription of genes encoding cytokines like IL-2, inhibits the replication of diverse coronaviruses at non-cytotoxic, low-micromolar concentrations in vitro (160).

\section{Hypersensitivity reactions}

Rare cases of pruritus, urticaria, angioedema and anaphylaxis were reported (161-163). The possible mechanisms can be both immunologic and non-immunologic, which seems to depend on the administration route and formulation (161). In some cases, DHRs have been attributed to the additives such as Castor oil (162), or Cremophor EL (163). SPTs and IDTs or basophil activation test (BAT) can be used for the diagnosis of cyclosporine- and additive-induced IgE-mediated IHRs $(18,161,163)$.

Colchicine

\section{Clinical use in COVID-19}

It is a non-selective inhibitor of NLRP3 inflammasome which is thought to be a major pathophysiologic component of ARDS and/or acute lung injury seen in COVID-19 (164).

\section{Hypersensitivity reactions}

Rare cases of anaphylaxis (148), confirmed FDE with DPT (165) and successfully desensitized MPE (166) were reported. For PTs, it is recommended to dilute colchicine to $1 \%$ in petrolatum (167).

Eculizumab

\section{Clinical use in COVID-19}

Eculizumab, a humanized anti-C5 monoclonal antibody, is under investigation as a candidate drug to play a role in the thrombotic microvascular injury mediated by complement activation causing lung injury either due to severe pneumonia or ARDS in severe COVID-19 $(21,36,168)$.

\section{Hypersensitivity reactions}

IHRs or infusion reactions due to eculizumab are very rare $(169,170)$. A case of anaphylaxis diagnosed with STs was sucessfully desensitized with a rapid protocol (171).

Glucocorticoids

\section{Clinical use in COVID-19}

In COVID-19 patients, the use of glucocorticoids (GCs) is rather controversial $(172,173)$. Early-start of GCs could be helpful for patients who have an overly exuberant inflammatory response or are at high risk of developing ARDS, whereas the benefit of GCs as rescue treatment remains doubtful (174).

\section{Hypersensitivity reactions}

IHRs to GCs are overall rare and mostly IgE-mediated (175-180). In a review of the literature from 20042014 , anaphylaxis was the most common manifestation reported (60.8\%,73/120 reactions) followed by urticaria and/or angioedema (26.7\%). Methylprednisolone was implicated in $41 \%$ of reactions, followed by prednisolone (20\%), triamcinolone (14\%), and hydrocortisone (10\%) (178). 
In most subjects with IHRs, it is possible to identify the culprit and safe alternative GCs by performing immediate-reading STs (175-182). In the aforementioned review, $74.1 \%$ of 112 STs carried out with GCs suspected of being responsible for reactions were positive (178). In some subjects, positive STs were associated with positive serum specific IgE assays and BATs $(178,179)$.

IHRs to medication components other than the GC itself, such as succinate ester used to enhance the solubility in parenteral preparations, have been described $(178,182)$. Hence, when evaluating a reaction to an esterified GC, it is advisable to include in STs the suspected GC and the same GC without the ester component, or with a different ester.

IHRs to excipients or preservatives in GC preparations, such as lactose, carboxymethylcellulose, polyethylene glycol, and hexylene glycol, have also been reported $(178,182)$. Therefore, testing should be performed with a preservative free GC, in addition to preservative testing per se if needed (182). A study proposed a comprehensive diagnostic algorithm to evaluate hypersensitivity reactions to GCs, as well as to their components and preservatives (182). This algorithm included STs with Carmellose@ eye drops in subjects who had reacted to carboxymethylcellulose-containing GCs and with cow's milk proteins in those who had reacted to lactose-containing GCs.

In the allergy workup, negative results in STs should be confirmed with DPTs (177-182). DPTs are also recommended to ensure tolerance of alternative preparations (181). Cross-reactivity patterns based on structural characteristics have not been clearly established for IHRs as they have been for allergic contact dermatitis (176). DPTs have shown that patients often tolerate alternative GCs belonging to the same chemical group as the responsible GC $(179,180)$. Desensitization to methylprednisolone has been successfully performed $(183,184)$.

NIHRs following systemic administration of GCs have been more rarely reported than IHRs; most reports concerned isolated cases of eczematous or exanthematous skin eruptions $(175,176)$. Some are systemic contact dermatitis, occurring in patients with previous contact dermatitis to GCs. They can be revealed by a Baboon syndrome, characterized by a buttock erythema associated to a symmetric, flexural erythema (185).

Most patients do not have a previous topical sensitization. In NIHRs, the main feature is MPE, but other clinical aspects can also occur such as annular erythema, erythroderma, SDRIFE, AGEP, FDE, and a few cases of SJS (185).

NIHRs can be T-cell-mediated, and PTs, together with delayed-reading IDTs, are useful tools for evaluating them (17). PTs have to be read at 2, 4 and also 7 days. Even though delayed-reading IDTs are more sensitive than PTs, the sensitivity of the former is limited. Therefore, DPTs are often necessary to diagnose NIHRs. In a study by Padial et al, only 2 of the 38 patients with NIHRs to GCs displayed positive delayed-reading IDTs and PTs to the responsible GCs (i.e., dexamethasone and betamethasone), while 21 of the 32 negative patients who agreed to undergo DPTs reacted to them, experiencing almost exclusively delayed-appearing urticarial eruptions or MPEs (186).

\section{ANTI-COAGULANT AND ANTI-AGGREGANT DRUGS USED FOR COAGULOPATHY}

Heparin and low molecular weight heparins (LMWHs)

\section{Clinical use in COVID-19}

Heparin [unfractionated heparin (UFH)] and LMWHs are administered for treatment or prophylaxis of thrombosis and therefore it is used for the coagulopathy observed during COVID-19 (187).

\section{Hypersensitivity reactions}

UFH may induce all types of DHRs, mostly type IV and type II (188). Cutaneous NIHRs to subcutaneous heparin occur at the injection site as itchy erythematous or eczematous plaques usually on the $7^{\text {th }}-10^{\text {th }}$ day of treatment; although they can appear on the $1-3^{\text {th }}$ day in case of antecedent sensitization (189). Risk factors for NIHRs to heparin are obesity, female gender, old age, pregnancy, and repeated exposures $(190,191)$. If 
the treatment is continued regardless of a local reaction, the patient may develop generalized eczema or exanthem $(192,193)$. Patients with a NIHR to UFH or LMWH at injection site usually tolerate intravenous administration of UFH (189). Cross-reactivity among LMWHs has been reported in NIHRs (194). However, fondaparinux is generally well-tolerated in patients who react to LMWHs (191). Heparin may induce DRESS (195) and SJS (196).

Immune-mediated heparin-induced thrombocytopenia (HIT) is induced by IgG antibodies against complex of heparin and platelet-factor 4 tetramers (197). HIT manifests as a more than $50 \%$ decrease in the platelet count in 5 to 10 days after the onset of treatment (198). The risk of HIT is increased exclusively with UFH (199). Treatment includes the discontinuation of heparin and the introduction of an alternative anticoagulant such as argatroban, fondaparinux, danaparoid, or bivalirudin (198).

The IgE-mediated reactions to heparin manifesting as urticaria, angioedema, and anaphylaxis are rare (194,200,201). Positive STs with UFH and LMWHs have been reported (194,200,201,202). Cross-reactivity in IHRs has been reported between UFH and LMWH and among LMWHs (202).

For IHRs with heparins, diagnostic approach primarily consists of SPTs and IDTs (17). The results of BAT with UFH and LMWH are controversial $(201,203,204)$. Heparin itself may cause a release of histamine, leading to a false positive ST. Further serial dilutions of heparin $(1: 100,1: 1.000,1: 10.000)$ might be needed (201). IDTs and PTs with the culprit and alternative heparin are performed in NIHRs (205). PTs, with tape stripping, are less sensitive but may be positive (188).

DPT is considered when the diagnosis is obscure, tissue pathology is unavailable, or an alternative anticoagulant needs to be determined (206). Subcutaneous DPTs with UFC and LMWHs are performed with increasing doses reaching up to a daily dose on the first day, then are evaluated on three consecutive days and day 7 in case of NIHRs. Intravenous DPTs with UFC may also be necessary to prove tolerance for emergency situations both for IHRs and NIHRs $(188,189)$. A standard protocol for UFH desensitization has not been established yet and published as case reports $(207,208)$.

Dipyridamole

\section{Clinical use in COVID-19}

Dipyridamole is an inhibitor of phosphodiesterase 3 and 5, thereby it increases intracellular cAMP and/or cGMP in platelets and inhibits platelet aggregation (209). Besides, it has antiviral features against several viruses $(210,211)$. Dipyridamole as an adjunctive therapy was demonstrated to be associated with decreased D-dimer levels in COVID-19 (212).

\section{Hypersensitivity reactions}

DHRs related to dipyridamole are extremely rare. An adult patient with delayed eczematous lesions revealed positive PT results (213). Anaphylaxis or anaphylaxis like reactions were escribed in two cases however they lack diagnostic tests $(214,215)$.

\section{CONCLUSION}

This review brings together all the published information about DHRs due to current and candidate off-label drugs to treat COVID-19. The current knowledge depends mostly on previous clinical experience and few published studies or case reports. In near future, we need to obtain data about DHRs during the disease from ongoing clinical trials and DHR registries. This review also highlights the presence of two different groups of disease-related exanthems. We think that it is extremely important to distinguish these disease-related eruptions from true DHR related skin manifestations considering that the majority of the drugs used are more associated with drug-related non-immediate skin reactions.

Hopefully, published literature reveals that most of these drugs rarely cause DHRs but severe reactions may also occur. Additionaly as time passes, we will observe if SARS-CoV2 can aggreviate T-cell mediated 
reactions as some viruses do (216), and if the hyperinflammation observed during the course of the disease may influence DHRs.

Considering the severity of the disease and the emergent need for interventions, it is important to give accurate and quick diagnostic and therapeutic decisions in case of DHRs. Therefore, the diagnosis can mostly rely on clinical observations without performing in vivotests which have possible contamination risks, and time consumingin vitro tests. If alternative drugs are not available and underlying DHR is not severe, we can recommend that drugs can be applied with published or tailored desensitization protocols $(19,20)$. When mild, self-limiting DHR is considered, 'treating through' concept, the continued administration of a drug despite a suspected allergic hypersensitivity reaction, can be considered under strict surveillance measures (217). Our recommendations for the diagnosis and management of DHRs due to drugs administered during COVID-19 are listed in Box-1.

\section{References}

1. Organization WH. Clinical management of severe acute respiratory infection (SARI) when COVID-19 disease is suspected.Interim guidance V 1.2. 2020.

2. Dong X, Cao YY, Lu XX, Zhang JJ, Du H, Yan YQ, et al. Eleven faces of coronavirus disease 2019. Allergy 2020.

3. Xu Y, Li X, Zhu B, Liang H, Fang C, Gong Y, et al. Characteristics of pediatric SARS-CoV-2 infection and potential evidence for persistent fecal viral shedding. Nat Med 2020;26(4):502-505.

4. Recalcati S. Cutaneous manifestations in COVID-19: a first perspective. J Eur Acad Dermatol Venereol 2020.

5. Monteagudo LA, Boothby A, Gertner E. Continuous Intravenous Anakinra Infusion to Calm the Cytokine Storm in Macrophage Activation Syndrome.ACR Open Rheumatol 2020.

6. Zhang C, Wu Z, Li JW, Zhao H, Wang GQ. The cytokine release syndrome (CRS) of severe COVID-19 and Interleukin-6 receptor (IL-6R) antagonist Tocilizumab may be the key to reduce the mortality. Int $J$ Antimicrob Agents 2020:105954.

7. Zhou M, Zhang X, Qu J. Coronavirus disease 2019 (COVID-19): a clinical update. Front Med 2020.

8. Sanders JM, Monogue ML, Jodlowski TZ, Cutrell JB. Pharmacologic Treatments for Coronavirus Disease 2019 (COVID-19): A Review.JAMA 2020.

9. Du YX, Chen XP. Favipiravir: Pharmacokinetics and Concerns About Clinical Trials for 2019-nCoV Infection. Clin Pharmacol Ther2020.

10. Health TMo. Turkish Ministry ofHealth COVID-19 Guideline 14.04.2020. 2020.

11. Direzione Generale Cura della Persona SeW. Indirizzi terapeutici della Regione E-R per il trattamento della infezione da SARS-CoV2 (COVID-19). 2020.

12. Garvey LH, Ebo DG, Mertes PM, Dewachter P, Garcez T, Kopac P, et al. An EAACI position paper on the investigation of perioperative immediate hypersensitivity reactions. Allergy2019;74(10):1872-1884.

13. Romano A, Atanaskovic-Markovic M, Barbaud A, Bircher AJ, Brockow K, Caubet JC, et al. Towards a more precise diagnosis of hypersensitivity to beta-lactams - an EAACI position paper. Allergy 2019.

14. Aberer W, Bircher A, Romano A, Blanca M, Campi P, Fernandez J, et al. Drug provocation testing in the diagnosis of drug hypersensitivity reactions: general considerations. Allergy 2003;58(9):854-863.

15. Brockow K, Ardern-Jones MR, Mockenhaupt M, Aberer W, Barbaud A, Caubet JC, et al. EAACI position paper on how to classify cutaneous manifestations of drug hypersensitivity. Allergy2019;74(1):1427.

16. Gomes ER, Brockow K, Kuyucu S, Saretta F, Mori F, Blanca-Lopez N, et al. Drug hypersensitivity in children: report from the pediatric task force of the EAACI Drug Allergy Interest Group. Allergy2016;71(2):149-161.

17. Brockow K, Garvey LH, Aberer W, Atanaskovic-Markovic M, Barbaud A, Bilo MB, et al. Skin test concentrations for systemically administered drugs - an ENDA/EAACI Drug Allergy Interest Group position paper.Allergy 2013;68(6):702-712 .

18. Mayorga C, Celik G, Rouzaire P, Whitaker P, Bonadonna P, Rodrigues-Cernadas J, et al. In vitro tests for drug hypersensitivity reactions: an ENDA/EAACI Drug Allergy Interest Group position 
paper.Allergy 2016;71(8):1103-1134.

19. Cernadas JR, Brockow K, Romano A, Aberer W, Torres MJ, Bircher A, et al. General considerations on rapid desensitization for drug hypersensitivity - a consensus statement. Allergy2010;65(11):1357-1366.

20. Scherer K, Brockow K, Aberer W, Gooi JH, Demoly P, Romano A, et al. Desensitization in delayed drug hypersensitivity reactions - an EAACI position paper of the Drug Allergy Interest Group. Allergy 2013;68(7):844-852.

21. Guan WJ, Ni ZY, Hu Y, Liang WH, Ou CQ, He JX, et al. Clinical Characteristics of Coronavirus Disease 2019 in China. N Engl J Med 2020.

22. Galván Casas C, Català A, Carretero Hernández G, Rodríguez-Jiménez P, Fernández Nieto D, Rodríguez-Villa Lario A, et al. Classification of the cutaneous manifestations of COVID-19: a rapid prospective nationwide consensus study in Spain with 375 cases. Br J Dermatol. 2020 Apr 29.

23. Henry D, Ackerman M, Sancelme E, Finon A, Esteve E. Urticarial eruption in COVID-19 infection. $J$ Eur Acad Dermatol Venereol2020.

24. Hunt M, Koziatek C. A Case of COVID-19 Pneumonia in a Young Male with Full Body Rash as a Presenting Symptom. Clin Pract Cases Emerg Med 2020.

25. Marzano AV, Genovese G, Fabbrocini G, Pigatto P, Monfrecola G, Piraccini BM, et al. Varicella-like exanthem as a specific COVID-19-associated skin manifestation: multicenter case series of 22 patients. J Am Acad Dermatol 2020.

26. Genovese G, Colonna C, Marzano AV. Varicella-like exanthem associated with COVID-19 in an 8-yearold girl: A diagnostic clue? Pediatr Dermatol 2020.

27. Jimenez-Cauhe J, Ortega-Quijano D, Prieto-Barrios M, Moreno-Arrones OM, Fernandez-Nieto D. Reply to "COVID-19 can present with a rash and be mistaken for Dengue": Petechial rash in a patient with COVID-19 infection. J Am Acad Dermatol 2020.

28. Hedou M, Carsuzaa F, Chary E, Hainaut E, Cazenave-Roblot F, Masson Regnault M. Comment on "Cutaneous manifestations in COVID-19: a first perspective" by Recalcati S. J Eur Acad Dermatol Venereol2020.

29. Gianotti R, Veraldi S, Recalcati S, Cusini M, Ghislanzoni M, Boggio F, et al. Cutaneous ClinicoPathological Findings in three COVID-19-Positive Patients Observed in the Metropolitan Area of Milan, Italy. Acta Derm Venereol 2020.

30. Joob B, Wiwanitkit V. COVID-19 can present with a rash and be mistaken for dengue. J Am Acad Dermatol 2020;82(5):e177.

31. Manalo IF, Smith MK, Cheeley J, Jacobs R. A Dermatologic Manifestation of COVID-19: Transient Livedo Reticularis. J Am Acad Dermatol2020.

32. Kolivras A, Dehavay F, D. D, Feoli F, Meiers I, Milone L, et al. Coronavirus (COVID-19) infectioninduced chilblains: a case report with histopathological findings. JAAD Case Reports 2020.

33. Mazzotta F, Troccoli T, Bonifazi E. A new vasculitis at the time of COVID-19. European Journal Of Pediatric Dermatology - pd online2020.

34. Fernandez-Ni" eto D, Jimenez-Cauhe J, Suarez-Valle A, Moreno-Arrones OM, Saceda-Corralo D, Arana-Raja A, et al. Characterization of acute acro-ischemic lesions in non-hospitalized patients: a case series of 132 patients during the COVID-19 outbreak. J Am Acad Dermatol. 2020 Apr 24. pii: S0190-9622(20)30709-X.

35. Zhang Y, Cao W, Xiao M, Li YJ, Yang Y, Zhao J, et al. [Clinical and coagulation characteristics of 7 patients with critical COVID-2019 pneumonia and acro-ischemia]. Zhonghua Xue Ye Xue Za Zhi2020;41(0):E006.

36. Magro C, Mulvey JJ, Berlin D, Nuovo G, Salvatore S, Harp J, et al. Complement associated microvascular injury and thrombosis in the pathogenesis of severe COVID-19 infection: A report of five cases. Transl Res 2020.

37. Zhai P, Ding Y, Wu X, Long J, Zhong Y, Li Y. The epidemiology, diagnosis and treatment of COVID19. Int J Antimicrob Agents2020:105955.

38. Li G, De Clercq E. Therapeutic options for the 2019 novel coronavirus (2019-nCoV). Nat Rev Drug Discov 2020;19(3):149-150. 
39. Jean SS, Lee PI, Hsueh PR. Treatment options for COVID-19: The reality and challenges. J Microbiol Immunol Infect 2020.

40. Costanzo M, De Giglio MAR, Roviello GN. SARS-CoV-2: Recent Reports on Antiviral Therapies Based on Lopinavir/Ritonavir, Darunavir/Umifenovir, Hydroxychloroquine, Remdesivir, Favipiravir and Other Drugs for the Treatment of the New Coronavirus. Curr Med Chem 2020.

41. Rosa SGV, Santos WC. Clinical trials on drug repositioning for COVID-19 treatment. Rev Panam Salud Publica. 2020;44:e40.

42. Jefferson T, Jones M, Doshi P, Spencer EA, Onakpoya I, Heneghan CJ. Oseltamivir for influenza in adults and children: systematic review of clinical study reports and summary of regulatory comments. BMJ2014;348:g2545.

43. Simin M, Brok J, Stimac D, Gluud C, Gluud LL. Cochrane systematic review: pegylated interferon plus ribavirin vs. interferon plus ribavirin for chronic hepatitis C. Aliment Pharmacol Ther2007;25(10):11531162.

44. Cao B, Wang Y, Wen D, Liu W, Wang J, Fan G, et al. A Trial of Lopinavir-Ritonavir in Adults Hospitalized with Severe COVID-19.N Engl J Med 2020.

45. Madruga JV, Berger D, McMurchie M, Suter F, Banhegyi D, Ruxrungtham K, et al. Efficacy and safety of darunavir-ritonavir compared with that of lopinavir-ritonavir at 48 weeks in treatment-experienced, HIV-infected patients in TITAN: a randomised controlled phase III trial. Lancet 2007;370(9581):49-58.

46. Zuo W, Wen LP, Li J, Mei D, Fu Q, Zhang B. Oseltamivir induced Stevens-Johnson syndrome/toxic epidermal necrolysis-case report.Medicine (Baltimore) 2019;98(19):e15553.

47. Gonzalez-Ramos J, Lamas C, Bellon T, Ruiz-Bravo E, Ramirez E, Lerma V, et al. Oseltamivir-induced toxic epidermal necrolysis in a patient with Cushing's disease. Indian J Dermatol Venereol Leprol 2019.

48. Grein J, Ohmagari N, Shin D, Diaz G, Asperges E, Castagna A, et al. Compassionate use of Remdesivir for Patients with Severe COVID-19.N Engl J Med 2020.

49. Brillanti S, Mazzella G, Roda E. Ribavirin for chronic hepatitis C: and the mystery goes on. Dig Liver Dis 2011;43(6):425-430.

50. Lorcy S, Gaudy-Marqueste C, Botta D, Portal I, Quiles N, Oulies V, et al. [Cutaneous adverse events of telaprevir/peginterferon/ribavirin therapy for chronic hepatitis C: A multicenter prospective cohort study]. Ann Dermatol Venereol 2016;143(5):336-346.

51. Patrk I, Morovic M, Markulin A, Patrk J. Cutaneous reactions in patients with chronic hepatitis C treated with peginterferon and ribavirin. Dermatology 2014;228(1):42-46.

52. Brok J, Gluud LL, Gluud C. Meta-analysis: ribavirin plus interferon vs. interferon monotherapy for chronic hepatitic C - an updated Cochrane review. Aliment Pharmacol Ther 2010;32(7):840-850.

53. Barreira P, Cadinha S, Malheiro D, da Silva JP. Delayed hypersensitivity to ribavirin confirmed by provocation test. J Investig Allergol Clin Immunol 2014;24(6):441-442.

54. Shindo M, Terai I. Adverse Skin Reactions due to Ribavirin in Hepatitis C Combination Therapy with Pegylated Interferon-alpha2a. Case Rep Dermatol 2013;5(3):379-381.

55. Ladd AM, Martel-Laferriere V, Dieterich D. Successful desensitization to ribavirin in a patient with chronic hepatitis C. J Clin Gastroenterol 2012;46(8):716-717.

56. Toker O, Tal Y, Daher S, Shalit M. Ribavirin Desensitization in Chronic Hepatitis C. Isr Med Assoc $J$ 2015;17(9):583-584.

57. Corbett AH, Lim ML, Kashuba AD. Kaletra (lopinavir/ritonavir).Ann Pharmacother 2002;36(78):1193-1203.

58. Ghosn J, Duvivier C, Tubiana R, Katlama C, Caumes E. Acute generalized exanthematous pustulosis induced by HIV postexposure prophylaxis with lopinavir-ritonavir. Clin Infect Dis 2005;41(9):13601361.

59. Echeverria P, Negredo E, Carosi G, Galvez J, Gomez JL, Ocampo A, et al. Similar antiviral efficacy and tolerability between efavirenz and lopinavir/ritonavir, administered with abacavir/lamivudine (Kivexa), in antiretroviral-naive patients: a 48-week, multicentre, randomized study (Lake Study). Antiviral Res 2010;85(2):403-408.

60. Sun L, Deng X, Chen X, Huang J, Huang S, Li Y, et al. Incidence of adverse drug reactions in COVID-10 
patients in China: An active monitoring study by hospital pharmacovigilance system. Clin Pharmacol Ther 2020 Apr 23.

61. Molina JM, Cohen C, Katlama C, Grinsztejn B, Timerman A, Pedro Rde J, et al. Safety and efficacy of darunavir (TMC114) with low-dose ritonavir in treatment-experienced patients: 24-week results of POWER 3. J Acquir Immune Defic Syndr 2007;46(1):24-31.

62. Buijs BS, van den Berk GE, Boateng CP, Hoepelman AI, van Maarseveen EM, Arends JE. Cross-reactivity between darunavir and trimethoprim-sulfamethoxazole in HIV-infected patients. AIDS2015;29(7):785-791.

63. Marcos Bravo MC, Ocampo Hermida A, Martinez Vilela J, Perez Rodriguez MT, Gavilan Montenegro MJ, Arenas Villarroel LJ, et al. Hypersensitivity reaction to darunavir and desensitization protocol.J Investig Allergol Clin Immunol 2009;19(3):250-251.

64. Lorber M, Haddad S. Hypersensitivity and desensitization to darunavir in a case of HIV infection with triple-class drug resistance: case description and review of the literature. J Int Assoc Provid AIDS Care 2013;12(6):378-379.

65. Hirschfeld G, Weber L, Renkl A, Scharffetter-Kochanek K, Weiss JM. Anaphylaxis after Oseltamivir (Tamiflu) therapy in a patient with sensitization to star anise and celery-carrot-mugwort-spice syndrome.Allergy 2008;63(2):243-244.

66. Tran DH, Sugamata R, Hirose T, Suzuki S, Noguchi Y, Sugawara A, et al. Azithromycin, a 15membered macrolide antibiotic, inhibits influenza A(H1N1)pdm09 virus infection by interfering with virus internalization process. J Antibiot (Tokyo) 2019;72(10):759-768.

67. Gautret P, Lagier JC, Parola P, Hoang VT, Meddeb L, Mailhe M, et al. Hydroxychloroquine and azithromycin as a treatment of COVID-19: results of an open-label non-randomized clinical trial. Int J Antimicrob Agents 2020:105949.

68. Araujo L, Demoly P. Macrolides allergy. Curr Pharm Des2008;14(27):2840-2862.

69. Mori F, Pecorari L, Pantano S, Rossi ME, Pucci N, De Martino M, et al. Azithromycin anaphylaxis in children. Int J Immunopathol Pharmacol 2014;27(1):121-126.

70. Barni S, Butti D, Mori F, Pucci N, Rossi ME, Cianferoni A, et al. Azithromycin is more allergenic than clarithromycin in children with suspected hypersensitivity reaction to macrolides. J Investig Allergol Clin Immunol 2015;25(2):128-132.

71. Schissel DJ, Singer D, David-Bajar K. Azithromycin eruption in infectious mononucleosis: a proposed mechanism of interaction. Cutis 2000;65(3):163-166.

72. Milkovic-Kraus S, Macan J, Kanceljak-Macan B. Occupational allergic contact dermatitis from azithromycin in pharmaceutical workers: a case series. Contact Dermatitis 2007;56(2):99-102.

73. Mendes-Bastos P, Bras S, Amaro C, Cardoso J. Non-occupational allergic contact dermatitis caused by azithromycin in an eye solution. J Dtsch Dermatol Ges 2014;12(8):729-730.

74. An I, Demir V, Akdeniz S. Fixed drug eruption probably induced by azithromycin. Australas J Dermatol 2017;58(4):e253-e254.

75. Campanon-Toro MV, Sierra O, Moreno E, Sobrino-Garcia M, Gracia-Bara MT, Davila I. Acute generalized exanthematous pustulosis (AGEP) induced by azithromycin. Contact Dermatitis 2017;76(6):363364 .

76. Sriratanaviriyakul N, Nguyen LP, Henderson MC, Albertson TE. Drug reaction with eosinophilia and systemic symptoms syndrome (DRESS) syndrome associated with azithromycin presenting like septic shock: a case report. J Med Case Rep 2014;8:332.

77. Aihara Y, Ito S, Kobayashi Y, Aihara M. Stevens-Johnson syndrome associated with azithromycin followed by transient reactivation of herpes simplex virus infection. Allergy 2004;59(1):118.

78. Xu L, Zhu Y, Yu J, Deng M, Zhu X. Nursing care of a boy seriously infected with Steven-Johnson syndrome after treatment with azithromycin: A case report and literature review. Medicine (Baltimore) 2018;97(1):e9112.

79. Odemis E, Kalyoncu M, Okten A, Yildiz K. Azithromycin-induced leukocytoclastic vasculitis. J Rheumatol 2003;30(10):2292.

80. Pursnani A, Yee H, Slater W, Sarswat N. Hypersensitivity myocarditis associated with azithromycin 
exposure. Ann Intern Med2009;150(3):225-226.

81. Empedrad R, Darter AL, Earl HS, Gruchalla RS. Nonirritating intradermal skin test concentrations for commonly prescribed antibiotics. J Allergy Clin Immunol 2003;112(3):629-630.

82. Won HK, Yang MS, Song WJ, Kim SH, Park HW, Chang YS, et al. Determination of nonirritating concentrations of antibiotics for intradermal skin tests in Korean adults. J Allergy Clin Immunol Pract 2017;5(1):192-194 e192.

83. Seitz CS, Brocker EB, Trautmann A. Suspicion of macrolide allergy after treatment of infectious diseases including Helicobacter pylori: results of allergological testing. Allergol Immunopathol (Madr)2011;39(4):193-199.

84. Unal D, Demir S, Gelincik A, Olgac M, Coskun R, Colakoglu B, et al. Diagnostic value of oral challenge testing in the diagnosis of macrolide hypersensitivity. J Allergy Clin Immunol Pract 2018;6:521-7.

85. Staso P, Leonov A. Drug desensitization in 17-year-old male with Mast Cell Activation Syndrome, pneumonia, and antibiotic hypersensitivities. AME Case Rep 2017;1:7.

86. Sinha N, Balayla G. Hydroxychloroquine and COVID-19. Postgrad Med J 2020.

87. Soria A, Barbaud A, Assier H, Avenel-Audran M, Tetart F, Raison-Peyron N, et al. Cutaneous Adverse Drug Reactions with Antimalarials and Allergological Skin Tests. Dermatology 2015;231(4):353-359.

88. Matsuda T, Ly NTM, Kambe N, Nguyen CTH, Ueda-Hayakawa I, Son Y, et al. Early cutaneous eruptions after oral hydroxychloroquine in a lupus erythematosus patient: A case report and review of the published work.J Dermatol 2018;45(3):344-348.

89. Sidoroff A, Dunant A, Viboud C, Halevy S, Bavinck JN, Naldi L, et al. Risk factors for acute generalized exanthematous pustulosis (AGEP)-results of a multinational case-control study (EuroSCAR). $\mathrm{Br} J$ Dermatol 2007;157(5):989-996.

90. Volpe A, Marchetta A, Caramaschi P, Biasi D, Bambara LM, Arcaro G. Hydroxychloroquine-induced DRESS syndrome. Clin Rheumatol2008;27(4):537-539.

91. Schmutz JL, Barbaud A, Trechot P. [Hydroxychloroquine and DRESS].Ann Dermatol Venereol 2008;135(12):903.

92. Girijala RL, Siddiqi I, Kwak Y, Wright D, Patel DB, Goldberg LH. Pustular DRESS Syndrome Secondary to Hydroxychloroquine With EBV Reactivation. J Drugs Dermatol 2019;18(2):207-209.

93. Perez-Ezquerra PR, de Barrio Fernandez M, de Castro Martinez FJ, Ruiz Hornillos FJ, Prieto Garcia A. Delayed hypersensitivity to hydroxychloroquine manifested by two different types of cutaneous eruptions in the same patient. Allergol Immunopathol (Madr)2006;34(4):174-175.

94. Phillips-Howard PA, Warwick Buckler J. Idiosyncratic reaction resembling toxic epidermal necrolysis caused by chloroquine and maloprim. Br Med J (Clin Res Ed) 1988;296(6636):1605.

95. Kanny G, Renaudin JM, Lecompte T, Moneret-Vautrin DA. Chloroquine hypersensitivity syndrome. Eur J Intern Med 2002;13(1):75-76.

96. Murphy M, Carmichael AJ. Fatal toxic epidermal necrolysis associated with hydroxychloroquine. Clin Exp Dermatol 2001;26(5):457-458.

97. Cameron MC, Word AP, Dominguez A. Hydroxychloroquine-induced fatal toxic epidermal necrolysis complicated by angioinvasive rhizopus. Dermatol Online J2014;20(11).

98. Lisi P, Assalve D, Hansel K. Phototoxic and photoallergic dermatitis caused by hydroxychloroquine. Contact Dermatitis 2004;50(4):255-256.

99. Meier H, Elsner P, Wuthrich B. [Occupationally-induced contact dermatitis and bronchial asthma in a unusual delayed reaction to hydroxychloroquine]. Hautarzt1999;50(9):665-669.

100. Charfi O, Kastalli S, Sahnoun R, Lakhoua G. Hydroxychloroquine-induced acute generalized exanthematous pustulosis with positive patch-testing. Indian J Pharmacol 2015;47(6):693-694.

101. Mates M, Zevin S, Breuer GS, Navon P, Nesher G. Desensitization to hydroxychloroquine-experience of 4 patients. J Rheumatol2006;33(4):814-816.

102. Caramaschi P, Barbazza R, Tinazzi I, Biasi D. Desensitization to hydroxychloroquine: 4 cases. $J$ Rheumatol 2011;38(10):2267; author reply 2267 .

103. Tal Y, Maoz Segal R, Langevitz P, Kivity S, Darnizki Z, Agmon-Levin N. Hydroxychloroquine desensitization, an effective method to overcome hypersensitivity-a multicenter experience. Lupus 
2018;27(5):703-707.

104. Barailler H, Milpied B, Chauvel A, Claraz P, Taieb A, Seneschal J, et al. Delayed hypersensitivity skin reaction to hydroxychloroquine: Successful short desensitization.J Allergy Clin Immunol Pract 2019;7(1):307-308.

105. Rowane M, Schend J, Patel J, Hostoffer R, Jr. Rapid desensitization of hydroxychloroquine.Ann Allergy Asthma Immunol 2020;124(1):97-98.

106. Donado CD, Diez EM. Successful desensitization for hydroxychloroquine anaphylaxis. J Rheumatol 2010;37(9):1975-1976. X

107. Perez-Sanchez N, Esponda-Juarez K, Cimarra Alvarez M, Aleo Lujan E, Toledano Martinez E, Fernandez-Rivas MM. Short desensitization in an adolescent with hydroxychloroquine anaphylaxis. Pediatr Allergy Immunol 2014;25(8):819-821.

108. Rothan HA, Stone S, Natekar J, Kumari P, Arora K, Kumar M. The FDA- approved gold drug Auranofin inhibits novel coronavirus (SARS-COV-2) replication and attenuates inflammation in human cells. https://www.biorxiv.org/content/10.1101/2020.04.14.041228v1.

109. Morgenstern B, Michaelis M, Baer PC, Doerr HW, Cinatl J, Jr. Ribavirin and interferon-beta synergistically inhibit SARS-associated coronavirus replication in animal and human cell lines. Biochem Biophys Res Commun 2005;326(4):905-908.

110. Sheahan TP, Sims AC, Leist SR, Schafer A, Won J, Brown AJ, et al. Comparative therapeutic efficacy of remdesivir and combination lopinavir, ritonavir, and interferon beta against MERS-CoV. Nat Commun 2020;11(1):222.

111. Vazquez-Lopez F, Manjon-Haces JA, Perez-Alvarez R, Perez-Oliva N. Eczema-like lesions and disruption of therapy in patients treated with interferon-alfa and ribavirin for chronic hepatitis $\mathrm{C}$ : the value of an interdisciplinary assessment.Br J Dermatol 2004;150(5):1046-1047; author reply 1047.

112. Kerl K, Negro F, Lubbe J. Cutaneous side-effects of treatment of chronic hepatitis C by interferon alfa and ribavirin. Br J Dermatol 2003;149(3):656.

113. Calabresi PA, Kieseier BC, Arnold DL, Balcer LJ, Boyko A, Pelletier J, et al. Pegylated interferon beta-1a for relapsing-remitting multiple sclerosis (ADVANCE): a randomised, phase 3, double-blind study. Lancet Neurol2014;13(7):657-665.

114. Milkiewicz P, Yim C, Pache I, Heathcote J. Diffuse skin reaction in patient with hepatitis B, treated with two different formulations of pegylated interferon.Can J Gastroenterol 2005;19(11):677-678.

115. Cottoni F, Bolognini S, Deplano A, Garrucciu G, Manzoni NE, Careddu GF, et al. Skin reaction in antiviral therapy for chronic hepatitis C: a role for polyethylene glycol interferon? Acta Derm Venereol 2004;84(2):120-123.

116. Poreaux C, Bronowicki JP, Debouverie M, Schmutz JL, Waton J, Barbaud A. Clinical allergy. Managing generalized interferon-induced eruptions and the effectiveness of desensitization. Clin Exp Allergy2014;44(5):756-764.

117. Sidhu-Malik NK, Kaplan AL. Multiple fixed drug eruption with interferon/ribavirin combination therapy for hepatitis C virus infection. J Drugs Dermatol 2003;2(5):570-573.

118. Conroy M, Sewell L, Miller OF, Ferringer T. Interferon-beta injection site reaction: review of the histology and report of a lupus-like pattern. J Am Acad Dermatol 2008;59(2 Suppl 1):S48-49.

119. Brown DL, Login IS, Borish L, Powers PL. An urticarial IgE-mediated reaction to interferon beta-1b. Neurology2001;56(10):1416-1417.

120. Kalpaklioglu FA, Baccioglu Kavut A, Erdemoglu AK. Desensitization in interferon-beta1a allergy: a case report. Int Arch Allergy Immunol 2009;149(2):178-180.

121. Cortellini G, Amadori A, Comandini T, Corvetta A. Interferon beta 1a anaphylaxis, a case report. Standardization of non-irritating concentration for allergy skin tests. Eur Ann Allergy Clin Immunol 2013;45(5):181-182.

122. Sakatani A, Doi Y, Matsuda T, Sasai Y, Nishida N, Sakamoto M, et al. Protracted anaphylaxis developed after peginterferon alpha-2a administration for chronic hepatitis C. World $J$ Gastroenterol2015;21(9):2826-2829.

123. Meller S, Erhardt A, Auci A, Neumann NJ, Homey B. Drug-induced exanthema caused by pegylated 
interferon-alpha 2b. Hautarzt2003;54(10):992-993.

124. Taghavi SA, Eshraghian A. Successful interferon desensitization in a patient with chronic hepatitis C infection. World J Gastroenterol2009;15(33):4196-4198.

125. Caly L, Druce JD, Catton MG, Jans DA, Wagstaff KM. The FDA-approved drug ivermectin inhibits the replication of SARS-CoV-2 in vitro. Antiviral Res2020;178:104787.

126. Ngwasiri CA, Abanda MH, Aminde LN. Ivermectin-induced fixed drug eruption in an elderly Cameroonian: a case report. J Med Case Rep 2018;12(1):254.

127. Kerneuzet I, Blind E, Darrieux L, Moreau S, Safa G. Ivermectin-induced drug reaction with eosinophilia and systemic symptoms (DRESS) syndrome. JAAD Case Rep 2018;4(6):524-527.

128. Aroke D, Tchouakam DN, Awungia AT, Mapoh SY, Ngassa SN, Kadia BM. Ivermectin induced StevenJohnsons syndrome: case report. BMC Res Notes 2017;10(1):179.

129. Seegobin K, Bueno E, Maharaj S, Ashby T, Brown M, Jones L. Toxic epidermal necrolysis after ivermectin. Am J Emerg Med2018;36(5):887-889.

130. Kelleni MT. Nitazoxanide/Azithromycin Combination for COVID-19: A Suggested New Protocol for COVID-19 Early Management. Pharmacol Res. 2020 Apr 30;104874.

131. Regnier Galvao V, Castells MC. Hypersensitivity to biological agents- Updated diagnosis, management and treatment. J Allegy Clin Immunol Pract. 2015;3:174-185.

132. Nakamura M, Tokura Y. Tocilizumab-induced erythroderma. Eur J Dermatol 2009;19(3):273-274.

133. Yoshiki R, Nakamura M, Tokura Y. Drug eruption induced by IL-6 receptor inhibitor tocilizumab. $J$ Eur Acad Dermatol Venereol2010;24(4):495-496.

134. Soyer O, Demir S, Bilginer Y, Batu ED, Sonmez HE, Arici ZS, et al. Severe hypersensitivity reactions to biological drugs in children with rheumatic diseases. Pediatr Allergy Immunol 2019;30(8):833-840.

135. Koc R, Sonmez HE, Cakan M, Karadag SG, Tanatar A, Cakmak F, et al. Drug reactions in children with rheumatic diseases receiving parenteral therapies: 9 years' experience of a tertiary pediatric rheumatology center. Rheumatol Int 2020;40(5):771-776.

136. Rocchi V, Puxeddu I, Cataldo G, Del Corso I, Tavoni A, Bazzichi L, et al. Hypersensitivity reactions to tocilizumab: role of skin tests in diagnosis. Rheumatology (Oxford) 2014;53(8):1527-1529.

137. Tetu P, Hamelin A, Moguelet P, Barbaud A, Soria A. Management of hypersensitivity reactions to Tocilizumab. Clin Exp Allergy2018;48(6):749-752.

138. Cortellini G, Mascella F, Simoncelli M, Lippolis D, Focherini MC, Cortellini F, et al. Effective Desensitization to Tocilizumab in Delayed Hypersensitivity Reaction. Pharmacology2018;102(1-2):114-116.

139. Ben Said B, Gerfaud-Valentin M, Seve P. Fatal DRESS syndrome under tocilizumab treatment for seronegative polyarthritis. J Allergy Clin Immunol Pract 2018;6(3):1048-1049.

140. Zuelgaray E, Domont F, Peiffer-Smadja N, Saadoun D, Cacoub P. Tocilizumab-Induced Drug Reaction With Eosinophilia and Systemic Symptoms Syndrome in Adult-Onset Still Disease. Ann Intern Med2017;167(2):141-142.

141. Villiger PM, Adler S, Kuchen S, Wermelinger F, Dan D, Fiege V, et al. Tocilizumab for induction and maintenance of remission in giant cell arteritis: a phase 2, randomised, double-blind, placebo-controlled trial. Lancet 2016;387(10031):1921-1927.

142. Izquierdo JH, Bonilla-Abadia F, Ochoa CD, Agualimpia A, Tobon GJ, Canas CA. Acute Generalized Exanthematous Pustulosis due to Tocilizumab in a Rheumatoid Arthritis Patient. Case Rep Rheumatol 2012;2012:517424.

143. Yasuoka R, Iwata N, Abe N, Kohagura T, Nakaseko H, Shimizu M, et al. Risk factors for hypersensitivity reactions to tocilizumab introduction in systemic juvenile idiopathic arthritis. Mod Rheumatol 2019;29(2):324-327.

144. den Broeder AA, de Jong E, Franssen MJ, Jeurissen ME, Flendrie M, van den Hoogen FH. Observational study on efficacy, safety, and drug survival of anakinra in rheumatoid arthritis patients in clinical practice. Ann Rheum Dis 2006;65(6):760-762.

145. Kaiser C, Knight A, Nordström D, Petterson T, Fransson J, Robertsson EF. Injection-site reactions upon Kineret (anakinra) administration: experiences and explanations. Rheumatol Int (2012) 32:295299. DOI 10.1007/s00296-011-2096-3. 
146. Soyyigit S, Kendirlinan R, Aydin O, Celik GE. Successful desensitization with anakinra in a case with immediate hypersensitivity reaction. Ann Allergy Asthma Immunol2014;113(3):325-326.

147. Desai D, Goldbach-Mansky R, Milner JD, Rabin RL, Hull K, Pucino F, et al. Anaphylactic reaction to anakinra in a rheumatoid arthritis patient intolerant to multiple nonbiologic and biologic diseasemodifying antirheumatic drugs. Ann Pharmacother 2009;43(5):967-972.

148. Yılmaz I, Turk M, Nazik Bahcecioglu S. Successful rapid subcutaneous desensitization to anakinra in a case with a severe immediate-type hypersensitivity reaction. Eur Ann Allergy Clin Immunol 2018;50(2):94-96.

149. Emmi G, Silvestri E, Cantarini L, Lopalco G, Cecchi L, Chiarini F, et al. Rapid desensitization to anakinra-related delayed reaction: Need for a standardized protocol. J Dermatol 2017;44(8):981-982.

150. Bendele A, Colloton M, Vrkljan M, Morris J, Sabados K. Cutaneous mast cell degranulation in rats receiving injections of recombinant human interleukin-1 receptor antagonist (rhIL-1ra) and/or its vehicle: possible clinical implications. J Lab Clin Med 1995;125(4):493-500.

151. Lu CC, Chen MY, Chang YL. Potential therapeutic agents against COVID-19: What we know so far? J Chin Med Assoc. 2020 Apr 1;10.1097/JCMA.0000000000000318.

152. Wells AF. Parrino J, Mangan EK, Paccaly A, Lin Y,. Xu C, et al. Immunogenicity of sarilumab monotherapy in patients with rheumatoid arthritis who were inadequate responders or intolerant to disease-modifying antirheumatic drugs. Rheumatol Ther (2019) 6:339-352.

153. Grom AA, Horne A, De Benedetti F. Macrophage activation syndrome in the era of biologic therapy. Nat Rev Rheumatol2016;12(5):259-268.

154. Favalli EG, Biggioggero M, Maioli G, Caporali R. Baricitinib for COVID-19: a suitable treatment? Lancet Infect Dis. 2020 Apr 3:S1473-3099(20)30262-0. doi: 10.1016/S1473-3099(20)30262-0.

155. Stebbing J, Phelan A, Griffin I, Tucker C, Oechsle O, Smith D, et al. COVID-19: combining antiviral and anti-inflammatory treatments. Lancet Infect Dis. 2020 Apr; 20(4): 400-402.

156. Fournier JB, Cummings F, Cannella J. Drug-associated skin lesions in a patient with myelofibrosis receiving ruxolitinib. Dermatol Online J. 2014 Oct 15;20(10). pii: 13030/qt2jg3q02x

157. Koumaki D, Koumaki V, Lagoudaki E, Bertsias G. Palmoplantar pustulosis-like eruption induced by baricitinib for treatment of rheumatoid athritis. Eur J Case rep Intern Med 2019; 19: 7(1):001383.

158. Doohan BJ, Cranwell WC, Varigos GA, De Cruz R. An urticarial drug eruption caused by tofacitinib for alopecia universalis. Dermatologic Therapy. 2019;32:e12933.

159. Shibata T, Muto J, Hirano Y, Hiroyuki T, Yanagishita T, Ohshima Y, et al. Palmoplantar pustulosislike eruption following tofacitinib therapy for juvenile idiopathic arthritis. Ohshima,JAAD Case Reports 2019;5:518-21.

160. de Wilde AH, Zevenhoven-Dobbe JC, van der Meer Y, Thiel V, Narayanan K, Makino S, et al. Cyclosporin A inhibits the replication of diverse coronaviruses. Journal of General Virology (2011), 92, 2542-2548. DOI 10.1099/vir.0.034983-0.

161. Volcheck GW, Van Dellen RG. Anaphylaxis to intravenous cyclosporine and tolerance to oral cyclosporine: case report and review. Ann Allergy Asthma Immunol 1998;80(2):159-163.

162. Kang SY, Sohn KH, Lee JO, Kim SH, Cho SH, Chang YS. Intravenous tacrolimus and cyclosporine induced anaphylaxis: what is next? Asia Pac Allergy 2015;5(3):181-186.

163. Ebo DG, Piel GC, Conraads V, Stevens WJ. IgE-mediated anaphylaxis after first intravenous infusion of cyclosporine. Ann Allergy Asthma Immunol 2001;87(3):243-245.

164. Deftereos SG, Siasos G, Giannopoulos G, Vrachatis DA, Angelidis C, Giotaki SG, et al. The Greek study in the Effects of Colchicine in Covid-19 complications prevention (GRECCO-19 study): rationale and study design. Hellenic J Cardiol J 2020 Apr 3;S1109-9666(20)30061-0. doi: 10.1016/j.hjc.2020.03.002.

165. Mochida K, Teramae H, Hamada T. Fixed drug eruption due to colchicine. Dermatology 1996;192:61.

166. Levinger U, Monselise A. Reporting a desensitization protocol for colchicine treatment. Clin Exp Rheumatol 2001;19(5 Suppl 24):S79.

167. Barbaud A, Trechot P, Reichert-Penetrat S, Commun N, Schmutz JL. Relevance of skin tests with drugs in investigating cutaneous adverse drug reactions. Contact Dermatitis. 2001 Nov;45(5):265-8. 
168. Diurno F, Numis FG, Porta G, Cirillo F, Maddaluno S, Ragozzino A, et al. Eculizumab treatment in patients with COVID-19: preliminary results from real life ASL Napoli 2 Nord experience. Eur Rev Med Pharmacol Sci 2020;24(7):4040-4047.

169. Misawa S, Kuwabara S, Sato Y, Yamaguchi N, Nagashima K, Katayama K, et al. Safety and efficacy of eculizumab in Guillain-Barre syndrome: a multicentre, double-blind, randomised phase 2 trial. Lancet Neurol 2018;17(6):519-529.

170. Rondeau E, Cataland SR, Al-Dakkak I, Miller B, Webb NJA, Landau D. Eculizumab Safety: FiveYear Experience From the Global Atypical Hemolytic Uremic Syndrome Registry. Kidney Int Rep 2019;4(11):1568-1576.

171. Lo R, Alexander S, Moss J, Siddiqi A, Liu A. Eculizumab hypersensitivity and desensitization in a toddler with atypical hemolytic uremic syndrome. J Allergy Clin Immunol Pract 2019;7(7):2409-2410.

172. Russell CD, Millar JE, Baillie JK. Clinical evidence does not support corticosteroid treatment for 2019-nCoV lung injury. Lancet2020;395(10223):473-475.

173. Zhou W, Liu Y, Tian D, Wang C, Wang S, Cheng J, et al. Potential benefits of precise corticosteroids therapy for severe 2019-nCoV pneumonia. Signal Transduct Target Ther 2020;5(1):18.

174. Li T, Lu H, Zhang W. Clinical observation and management of COVID-19 patients. Emerg Microbes Infect 2020;9(1):687-690.

175. Ventura MT, Calogiuri GF, Muratore L, Di Leo E, Buquicchio R, Ferrannini A, et al. Cross-reactivity in cell-mediated and IgE-mediated hypersensitivity to glucocorticoids. Curr Pharm Des 2006;12(26):33833391.

176. Baeck M, Marot L, Nicolas JF, Pilette C, Tennstedt D, Goossens A. Allergic hypersensitivity to topical and systemic corticosteroids: a review. Allergy 2009;64(7):978-994.

177. Baker A, Empson M, The R, Fitzharris P. Skin testing for immediate hypersensitivity to corticosteroids: a case series and literature review. Clin Exp Allergy 2015;45(3):669-676.

178. Patel A, Bahna SL. Immediate hypersensitivity reactions to corticosteroids. Ann Allergy Asthma Immunol 2015;115(3):178-182 e173.

179. Aranda A, Mayorga C, Ariza A, Dona I, Blanca-Lopez N, Canto G, et al. IgE-mediated hypersensitivity reactions to methylprednisolone.Allergy 2010;65(11):1376-1380.

180. Venturini M, Lobera T, del Pozo MD, Gonzalez I, Blasco A. Immediate hypersensitivity to corticosteroids. J Investig Allergol Clin Immunol 2006;16(1):51-56.

181. Rachid R, Leslie D, Schneider L, Twarog F. Hypersensitivity to systemic corticosteroids: an infrequent but potentially life-threatening condition. J Allergy Clin Immunol2011;127(2):524-528.

182. Li PH, Wagner A, Thomas I, Watts TJ, Rutkowski R, Rutkowski K. Steroid Allergy: Clinical Features and the Importance of Excipient Testing in a Diagnostic Algorithm. J Allergy Clin Immunol Pract2018;6(5):1655-1661.

183. Angel-Pereira D, Berges-Gimeno MP, Madrigal-Burgaleta R, Urena-Tavera MA, Zamora-Verduga M, Alvarez-Cuesta E. Successful rapid desensitization to methylprednisolone sodium hemisuccinate: a case report. J Allergy Clin Immunol Pract 2014;2(3):346-348.

184. Guvenir H, Misirlioglu ED, Aydin F, Ece D, Cakar N, Kocabas CN. Successful methylprednisolone desensitization in a pediatric patient. Pediatr Allergy Immunol2017;28(3):305-306.

185. Barbaud A, Waton J. Systemic Allergy to Corticosteroids: Clinical Features and Cross Reactivity. Curr Pharm Des. 2016;22(45):6825-6831.

186. Padial A, Posadas S, Alvarez J, Torres MJ, Alvarez JA, Mayorga C, et al. Nonimmediate reactions to systemic corticosteroids suggest an immunological mechanism. Allergy 2005;60(5):665-670.

187. Zhai Z, Li C, Chen Y, Gerotziafas G, Zhang Z, Wan J, et al. Prevention and Treatment of Venous Thromboembolism Associated with Coronavirus Disease 2019 Infection: A Consensus Statement before Guidelines. Thromb Haemost 2020.

188. Bircher AJ, Harr T, Hohenstein L, Tsakiris DA. Hypersensitivity reactions to anticoagulant drugs: diagnosis and management options. Allergy2006;61(12):1432-1440.

189. Trautmann A, Seitz CS. Heparin allergy: delayed-type non-IgE-mediated allergic hypersensitivity to subcutaneous heparin injection. Immunol Allergy Clin North Am2009;29(3):469-480. 
190. Bank I, Libourel EJ, Middeldorp S, Van Der Meer J, Buller HR. High rate of skin complications due to low-molecular-weight heparins in pregnant women. $J$ Thromb Haemost 2003;1(4):859-861.

191. Tan E, Thompson G, Ekstrom C, Lucas M. Non-immediate heparin and heparinoid cutaneous allergic reactions: a role for fondaparinux. Intern Med J2018;48(1):73-77.

192. Kim KH, Lynfield Y. Enoxaparin-induced generalized exanthem. Cutis2003;72(1):57-60.

193. Seitz CS, Brocker EB, Trautmann A. Management of allergy to heparins in postoperative care: subcutaneous allergy and intravenous tolerance. Dermatol Online J2008;14(9):4.

194. Rodriguez-Fernandez A, Sanchez-Dominguez M, Torrado-Espanol I, Noguerado-Mellado B, RojasPerez-Ezquerra P. Clinical Patterns of Heparin Allergy: Cross-reactivity Between Low-MolecularWeight Heparins and Unfractionated Heparins. J Investig Allergol Clin Immunol 2019;29(2):132-134.

195. Ronceray S, Dinulescu M, Le Gall F, Polard E, Dupuy A, Adamski H. Enoxaparin-Induced DRESS Syndrome. Case Rep Dermatol 2012;4(3):233-237.

196. Bidaki R, Saeidi SA, Zarch MB. Delirious State and Agitation Following Heparin Induced StevensJohnson Syndrome. J Clin Diagn Res 2017;11(5):VL01.

197. Greinacher A, Potzsch B, Amiral J, Dummel V, Eichner A, Mueller-Eckhardt C. Heparin-associated thrombocytopenia: isolation of the antibody and characterization of a multimolecular PF4-heparin complex as the major antigen. Thromb Haemost 1994;71(2):247-251.

198. Greinacher A. Heparin-Induced Thrombocytopenia. N Engl J Med 2015;373(19):1883-1884.

199. Martel N, Lee J, Wells PS. Risk for heparin-induced thrombocytopenia with unfractionated and lowmolecular-weight heparin thromboprophylaxis: a meta-analysis.Blood 2005;106(8):2710-2715.

200. Berkun Y, Haviv YS, Schwartz LB, Shalit M. Heparin-induced recurrent anaphylaxis. Clin Exp Allergy 2004;34(12):1916-1918.

201. Anders D, Trautmann A. Allergic anaphylaxis due to subcutaneously injected heparin. Allergy Asthma Clin Immunol 2013;9(1):1.

202. Cesana P, Scherer K, Bircher AJ. Immediate Type Hypersensitivity to Heparins: Two Case Reports and a Review of the Literature. Int Arch Allergy Immunol2016;171(3-4):285-289.

203. Leguisamo S, Prados Castano M, Pinero Saavedra M, Cimbollek S. Recurrent Anaphylaxis Due to Enoxaparin. J Investig Allergol Clin Immunol2015;25(4):297-299.

204. Caballero MR, Fernandez-Benitez M. Allergy to heparin: a new in vitro diagnostic technique. Allergol Immunopathol (Madr)2003;31(6):324-328.

205. Kishimoto TK, Viswanathan K, Ganguly T, Elankumaran S, Smith S, Pelzer K, et al. Contaminated heparin associated with adverse clinical events and activation of the contact system. $N$ Engl $J$ Med2008;358(23):2457-2467.

206. Schindewolf M, Lindhoff-Last E, Ludwig RJ, Boehncke WH. Heparin-induced skin lesions. Lancet2012;380(9856):1867-1879.

207. Parekh K, Burkhart HM, Hatab A, Ross A, Muller BA. Heparin allergy: successful desensitization for cardiopulmonary bypass. J Thorac Cardiovasc Surg 2005;130(5):1455-1456.

208. Patriarca G, Rossi M, Schiavino D, Schinco G, Fais G, Varano C, et al. Rush desensitization in heparin hypersensitivity: a case report. Allergy 1994;49(4):292-294.

209. Gresele P, Momi S, Falcinelli E. Anti-platelet therapy: phosphodiesterase inhibitors. Br J Clin Pharmacol2011;72(4):634-646.

210. Tonew E, Indulen MK, Dzeguze DR. Antiviral action of dipyridamole and its derivatives against influenza virus A. Acta Virol 1982;26(3):125-129.

211. Fata-Hartley CL, Palmenberg AC. Dipyridamole reversibly inhibits mengovirus RNA replication. $J$ Virol 2005;79(17):11062-11070.

212. Liu X, Li Z, Liu S, Sun J, Chen Z, Jiang M, et al. Potential therapeutic effects of dipyridamole in the severely ill patients with COVID-19. Acta Pharm Sin B 2020.

213. Salava A, Alanko K, Hyry H. Dipyridamole-induced eczematous drug eruption with positive patch test reaction. Contact Dermatitis 2012;67(2):103-104.

214. Angelides S, Van der Wall H, Freedman SB. Acute reaction to dipyridamole during myocardial scintigraphy. $N$ Engl J Med 1999;340(5):394. 
215. Weinmann P, Moretti JL, Leynadier F. Anaphylaxis-like reaction induced by dipyridamole during myocardial scintigraphy. Am J Med 1994;97(5):488.

216. Pichler WJ. Immune pathomechanism and classification of drug hypersensitivity. Allergy 2019;74(8):1457-1471.

217. Trautmann A, Benoit S, Goebeler M, Stoevesandt J. !Treating through! Decision and follow-up in antibiotic therapy-associated exanthemas. J Allergy Clin Immunol Pract 2017: 5(6):1650-1656.

Table 1. Skin manifestations reported associated with COVID-19

\begin{tabular}{|c|c|c|c|c|}
\hline Manifestation & $\begin{array}{l}\text { Clinical } \\
\text { description }\end{array}$ & $\begin{array}{l}\text { Relative } \\
\text { frequency* }\end{array}$ & Specificity & References \\
\hline $\begin{array}{l}\text { 1. Skin } \\
\text { manifestations } \\
\text { similar to those } \\
\text { in other viral } \\
\text { infections }\end{array}$ & $\begin{array}{l}\text { 1. Skin } \\
\text { manifestations } \\
\text { similar to those } \\
\text { in other viral } \\
\text { infections }\end{array}$ & $\begin{array}{l}\text { 1. Skin } \\
\text { manifestations } \\
\text { similar to those } \\
\text { in other viral } \\
\text { infections }\end{array}$ & $\begin{array}{l}\text { 1. Skin } \\
\text { manifestations } \\
\text { similar to those } \\
\text { in other viral } \\
\text { infections }\end{array}$ & $\begin{array}{l}\text { 1. Skin } \\
\text { manifestations } \\
\text { similar to those } \\
\text { in other viral } \\
\text { infections }\end{array}$ \\
\hline Acute urticaria & $\begin{array}{l}\text { Sudden } \\
\text { appearance of } \\
\text { wheals with a } \\
\text { fleeting nature. } \\
\text { Continual } \\
\text { appearance and } \\
\text { disappearance of } \\
\text { new lesions is } \\
\text { characteristic. }\end{array}$ & Moderate & $\begin{array}{l}\text { Unspecific for } \\
\text { COVID-19; } \\
\text { infections are } \\
\text { common elicitors } \\
\text { for acute urticaria }\end{array}$ & $4,22,23,28$ \\
\hline $\begin{array}{l}\text { Maculopapular } \\
\text { exanthem } \\
\text { ("erythematous } \\
\text { rash") }\end{array}$ & $\begin{array}{l}\text { Acute erupting, } \\
\text { widespread } \\
\text { distribution of } \\
\text { multiple small, } \\
\text { round to oval } \\
\text { erythematous } \\
\text { macules and/or } \\
\text { papules with } \\
\text { different degrees } \\
\text { of confluence. } \\
\text { Mostly trunk, low } \\
\text { pruritus. }\end{array}$ & High & $\begin{array}{l}\text { Unspecific for } \\
\text { COVID-19; } \\
\text { infections are } \\
\text { common elicitors } \\
\text { for maculopapular } \\
\text { exanthem }\end{array}$ & $4,21,22,24,28,29$ \\
\hline $\begin{array}{l}\text { Varicella-like } \\
\text { exanthem } \\
\text { ("chickenpox-like } \\
\text { rash") }\end{array}$ & $\begin{array}{l}\text { Monomorphic } \\
\text { papulovesicular } \\
\text { skin eruption. } \\
\text { Erythematous } \\
\text { papules and } \\
\text { vesicles bilaterally } \\
\text { and } \\
\text { symmetrically } \\
\text { mostly on the } \\
\text { trunk. }\end{array}$ & High & $\begin{array}{l}\text { May be more } \\
\text { specific, vesicles } \\
\text { are quite } \\
\text { uncommon for } \\
\text { virus exanthems } \\
\text { and more specific } \\
\text { for varicella }\end{array}$ & $4,22,25,26$ \\
\hline
\end{tabular}




\begin{tabular}{|c|c|c|c|c|}
\hline Manifestation & $\begin{array}{l}\text { Clinical } \\
\text { description }\end{array}$ & $\begin{array}{l}\text { Relative } \\
\text { frequency* }\end{array}$ & Specificity & References \\
\hline $\begin{array}{l}\text { Symmetrical } \\
\text { intertriginous } \\
\text { exanthem }\end{array}$ & $\begin{array}{l}\text { Flexural } \\
\text { erythematous } \\
\text { maculopapular } \\
\text { exanthem on } \\
\text { axillary lesions } \\
\text { and trunk } \\
\text { +/-antecubal } \\
\text { fossae. }\end{array}$ & Two case reports & Unclear & 27 \\
\hline $\begin{array}{l}\text { 2. Skin } \\
\text { manifestations } \\
\text { associated with } \\
\text { vascular } \\
\text { pathologies }\end{array}$ & $\begin{array}{l}\text { 2. Skin } \\
\text { manifestations } \\
\text { associated with } \\
\text { vascular } \\
\text { pathologies }\end{array}$ & $\begin{array}{l}\text { 2. Skin } \\
\text { manifestations } \\
\text { associated with } \\
\text { vascular } \\
\text { pathologies }\end{array}$ & $\begin{array}{l}\text { 2. Skin } \\
\text { manifestations } \\
\text { associated with } \\
\text { vascular } \\
\text { pathologies }\end{array}$ & $\begin{array}{l}\text { 2. Skin } \\
\text { manifestations } \\
\text { associated with } \\
\text { vascular } \\
\text { pathologies }\end{array}$ \\
\hline $\begin{array}{l}\text { Purpuric exanthem } \\
\text { ("purpuric rash") }\end{array}$ & $\begin{array}{l}\text { Skin rash with } \\
\text { petechiae. }\end{array}$ & Moderate & $\begin{array}{l}\text { Unclear, potentially } \\
\text { more specific as } \\
\text { uncommon in other } \\
\text { viral exanthems, } \\
\text { except e.g. } \\
\text { Parvovirus B19 }\end{array}$ & 22,30 \\
\hline $\begin{array}{l}\text { Erythema ab igne } \\
\text { ("livedo } \\
\text { reticularis") }\end{array}$ & $\begin{array}{l}\text { Transient macular } \\
\text { erythema in a } \\
\text { broad reticular } \\
\text { pattern on thigh } \\
\text { unilaterally. }\end{array}$ & Case report & $\begin{array}{l}\text { Unclear, may be } \\
\text { more specific, if } \\
\text { causality can be } \\
\text { confirmed }\end{array}$ & 31 \\
\hline $\begin{array}{l}\text { Chilblain-like } \\
\text { lesions }\end{array}$ & $\begin{array}{l}\text { Acute-onset, } \\
\text { violaceous, } \\
\text { infiltrated and } \\
\text { painful plaques on } \\
\text { the toes and } \\
\text { lateral feet. } \\
\text { Vesicles and } \\
\text { erosions may be } \\
\text { present. }\end{array}$ & High & $\begin{array}{l}\text { Probably more } \\
\text { specific, if } \\
\text { causality can be } \\
\text { confirmed }\end{array}$ & $22,32,33,34$ \\
\hline $\begin{array}{l}\text { Cutaneous } \\
\text { acro-ischemia }\end{array}$ & $\begin{array}{l}\text { Finger and toe } \\
\text { cyanosis, purpura, } \\
\text { hematoma, skin } \\
\text { bulla and dry } \\
\text { gangrene. }\end{array}$ & $\begin{array}{l}\text { Moderate, } \\
\text { critically ill } \\
\text { patients with } \\
\text { coagulation crisis } \\
\text { and microvascular } \\
\text { injury }\end{array}$ & $\begin{array}{l}\text { More specific, as } \\
\text { uncommon for } \\
\text { viral disease }\end{array}$ & 35,36 \\
\hline
\end{tabular}

*Frequency of this skin manifestation in comparison to all described skin manifestations in COVID-19 infections

Table 2. Hypersensitivity reactions due to drugs with antiviral properties investigated for the treatment of COVID-19 in clinical trials or in vitro studies 


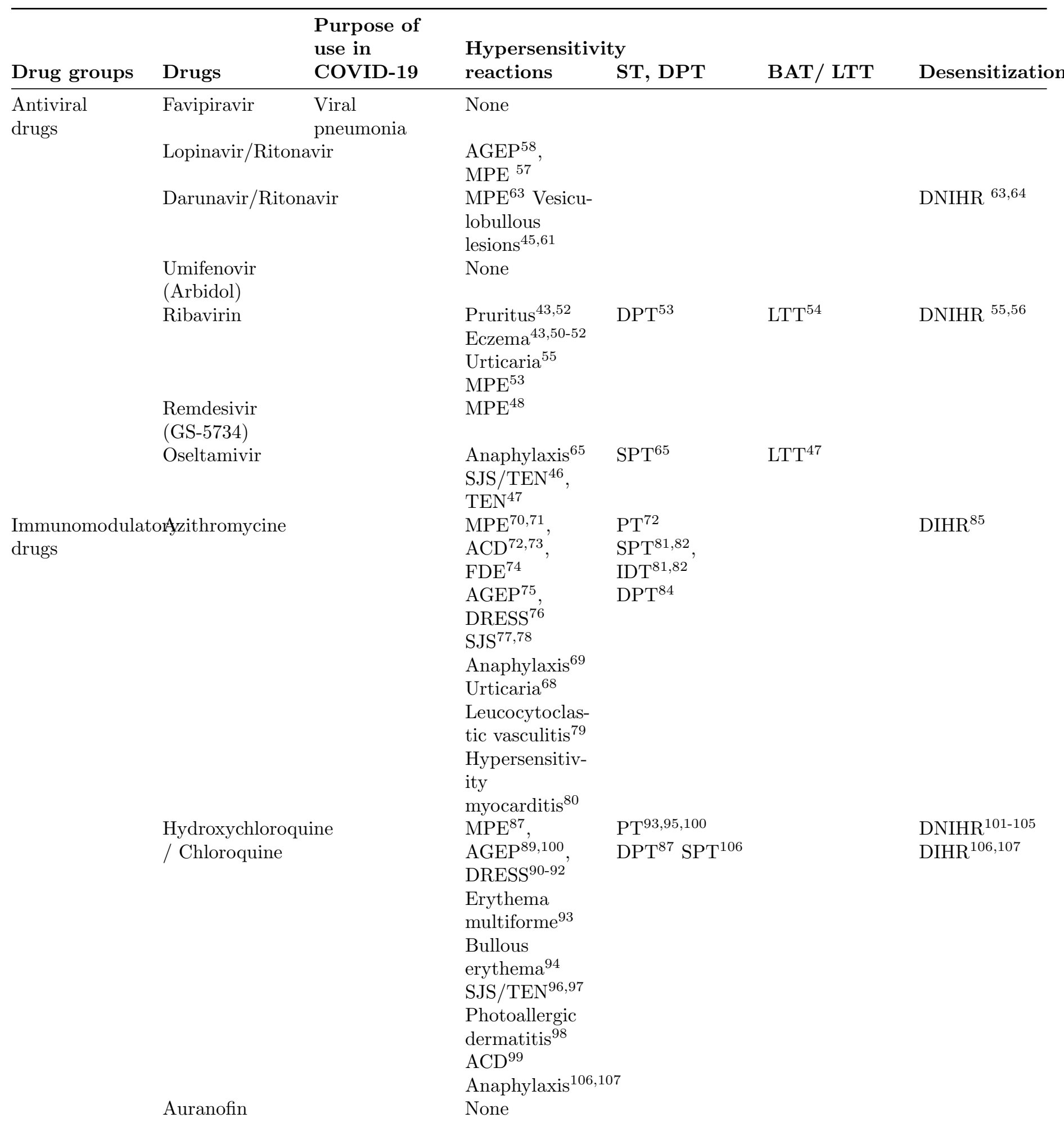




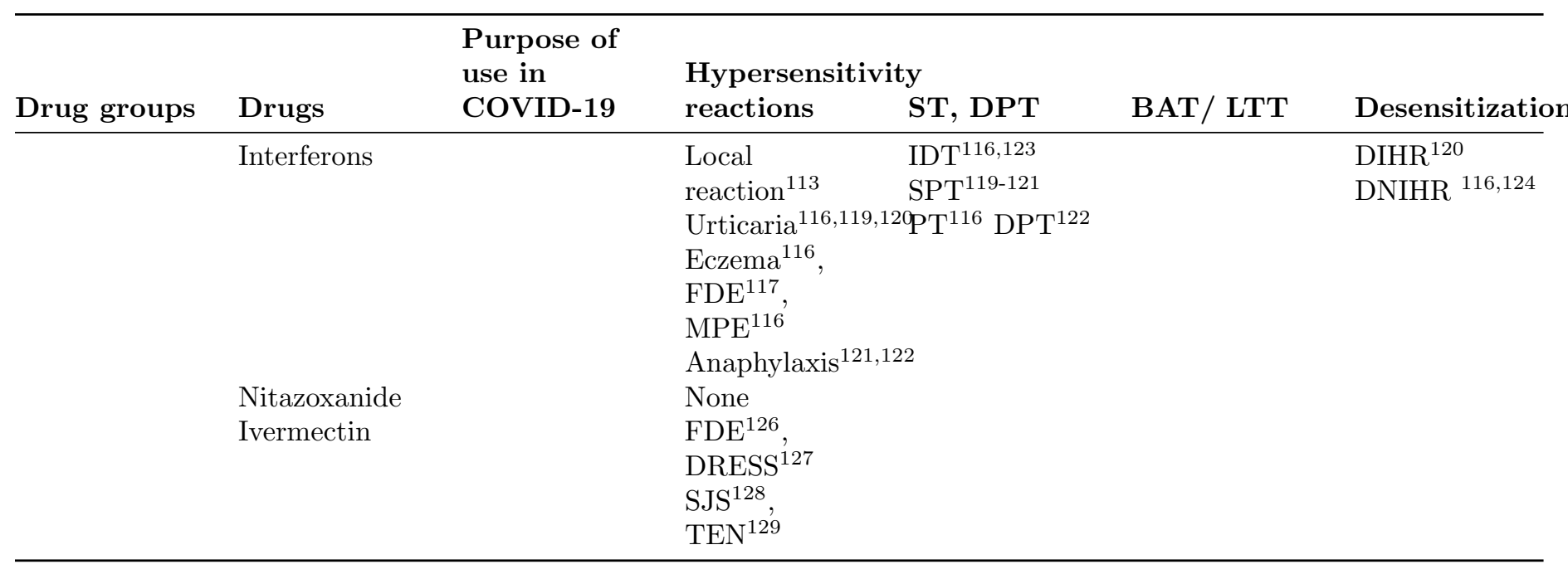

ACD: Acute contact dermatitis; AGEP: Acute generalized exanthematous pustulosis; BAT: Basophil activation test; DIHR: Desensitization for immediate hypersensitivity reactions; DNIHR: Desensitization for non-immediate hypersensitivity reactions; DPT: Drug provocation test; DRESS: Drug related eosinophilia systemic symptoms; FDE: Fixed drug eruption; IDT: Intradermal test; IHR: Immediate hypersensitivity reaction; LTT: Lymphocyte transformation test; MPE: Maculopapular eruption; NIHR: Non-immediate hypersensitivity reaction; PT: Patch test; SJS: Stevens Johnson syndrome; SPT: Skin prick test; ST: Skin test; TEN: Toxic epidermal necrolysis

Table 3. Hypersensitivity reactions due to other drugs investigated for the treatment of COVID-19 related complications in clinical trials or in vitro studies

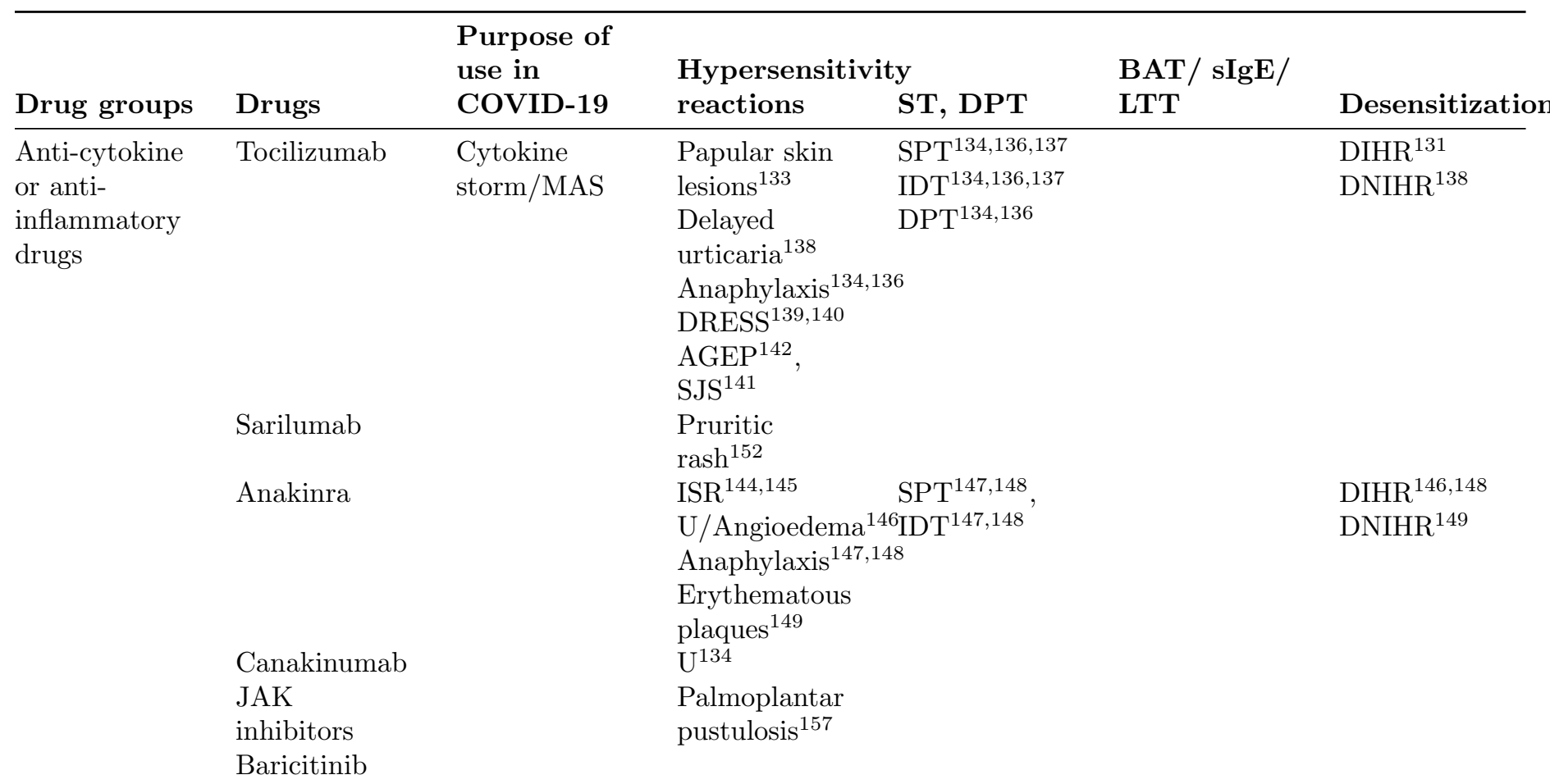




\begin{tabular}{|c|c|c|c|c|c|c|}
\hline Drug groups & Drugs & $\begin{array}{l}\text { Purpose of } \\
\text { use in } \\
\text { COVID-19 }\end{array}$ & $\begin{array}{l}\text { Hypersensitiv } \\
\text { reactions }\end{array}$ & ST, DPT & $\begin{array}{l}\text { BAT/ sIgE/ } \\
\text { LTT }\end{array}$ & Desensitizatio \\
\hline \multirow{5}{*}{$\begin{array}{l}\text { Anti- } \\
\text { inflammatory } \\
\text { drugs }\end{array}$} & $\begin{array}{l}\text { JAK } \\
\text { inhibitors } \\
\text { Ruxolitinib } \\
\text { JAK inhibitors } \\
\text { Tofacitinib }\end{array}$ & & $\begin{array}{l}\text { morbiliform } \\
\text { rash, } \\
\text { exfoliative } \\
\text { dermatitis }^{156} \\
\mathrm{U}^{158} \\
\text { palmoplantar } \\
\text { pustulosis }^{159}\end{array}$ & & & \\
\hline & Cyclosporine & & Anaphylaxis ${ }^{161-}$ & $\begin{array}{l}\mathrm{SPT}^{161,163} \\
\text { IDT }^{161,163}\end{array}$ & $\mathrm{BAT}^{163}$ & \\
\hline & Glucocorticoids & $\begin{array}{l}\text { Cytokine } \\
\text { storm/MAS } \\
\text { ARDS }\end{array}$ & $\begin{array}{l}\mathrm{IHR}^{175-180} \\
\mathrm{NIHR}^{175,176} \\
\mathrm{ACD}^{176}\end{array}$ & $\begin{array}{l}\mathrm{ST}^{175-182} \\
\mathrm{DPT}^{177-182} \\
\mathrm{PT}^{176,186} \\
\mathrm{IDT}^{176,186} \\
\mathrm{DPT}^{176,186}\end{array}$ & $\begin{array}{l}\operatorname{sIgE}^{178,179} \\
\text { BAT }^{178,179}\end{array}$ & $\operatorname{DIHR}^{183,184}$ \\
\hline & Colchicine & & $\begin{array}{l}\text { Anaphylaxis }{ }^{148} \\
\text { FDE }^{165} \\
\text { MPE }^{166}\end{array}$ & $\mathrm{DPT}^{165} \mathrm{PT}^{167}$ & & DNIHR $^{166}$ \\
\hline & Eculizumab & & $\begin{array}{l}\text { IHR }^{169-171} \\
\text { Anaphylaxis }^{171}\end{array}$ & $\begin{array}{l}\mathrm{SPT}^{171} \\
\mathrm{IDT}^{171}\end{array}$ & & $\operatorname{DIHR}^{171}$ \\
\hline \multirow[t]{2}{*}{$\begin{array}{l}\text { Anti-coagulant } \\
\text { or } \\
\text { anti-aggregant } \\
\text { drugs }\end{array}$} & $\begin{array}{l}\text { Heparin } \\
\text { Enoxaparin }\end{array}$ & Coagulopathy & $\begin{array}{l}\text { ISR }^{189} \\
\text { GDE }^{192,193} \\
\text { DRESS }^{195} \\
\text { SJS }^{196} \\
\text { HIT }^{197-199} \\
\text { IHR }^{194,201}\end{array}$ & $\begin{array}{l}\mathrm{SPT}^{205} \\
\mathrm{IDT}^{205} \mathrm{PT}^{205} \\
\mathrm{DPT}^{188,189}\end{array}$ & $\mathrm{BAT}^{201,203,204}$ & DIHR $^{207,208}$ \\
\hline & Dipyridamole & & $\begin{array}{l}\text { Eczema }^{213} \\
\text { Anaphylaxis }\end{array}$ & $\mathrm{PT}_{5}^{213}$ & & \\
\hline
\end{tabular}

ACD: Acute contact dermatitis; AGEP: Acute generalized exanthematous pustulosis; BAT: Basophil activation test; DIHR: Desensitization for immediate hypersensitivity reactions; DNIHR: Desensitization for non-immediate hypersensitivity reactions; DPT: Drug provocation test; DRESS: Drug related eosinophilia systemic symptoms; FDE: Fixed drug eruption; HIT: Heparin induced thrombocytopenia; IDT: Intradermal test; IHR: Immediate hypersensitivity reaction; Injection site reaction: ISR; Generalized delayed exanthema: GDE; LTT: Lymphocyte transformation test; MPE: Maculopapular eruption; NIHR: Non-immediate hypersensitivity reaction; PT: Patch test; SJS: Stevens Johnson syndrome; SPT: Skin prick test; ST: Skin test; TEN: Toxic epidermal necrolysis; Urticaria: U

\section{Box 1. Recommendations for diagnosis and management of DHRs in COVID-19}

- No equivalent alternatives for the currently off-label repurposed drugs or novel drugs used in COVID-19 do exist.

- We should extrapolate our knowledge on DHRs from other clinical situations to COVID-19 considering the scarse experience for the DHRs during the disease.

- Various drugs being used in different phases of the disease seem to cause rare but potentially severe DHRs, mostly non-immediate cutaneous hypersensitivity reactions based on data from limited number of case reports.

- The most important differential diagnosis of these DHRs is disease related exanthems, which can further be classified into the ones similar to those in other viral infections and the others related to 
thrombovascular events and vascular pathologies seen during COVID-19.

- Experience of diagnostic and management methods for DHRs due to the drugs used in COVID-19 depend mostly on few case reports or series.

- Knowledge of DHRs is urgently needed from pharmacovigilance registries and data from ongoing clinical trials of COVID-19.

- Quick diagnostic and therapeutic decisions in case of DHRs during COVID-19 are mandatory.

- Clinical diagnosis of DHRs during COVID-19 might mostly rely on clinical observations and basic laboratory findings regarding the need of urgent treatment of COVID-19.

- If the risks of a DHR outweigh the benefits obtained from the drug administration, the offending drug should be discontinued.

- If an alternative drug cannot be replaced, the offending drug can be administered via desensitization with published or tailored protocols when there are no contraindications.

- 'Treating through' concept, the continued administration of a drug despite a suspected allergic hypersensitivity reaction, can also be considered under strict surveillance measures if the underlying DHR is mild and self-limiting, and an alternative drug does not exist.

\section{Figure legends}

Figure 1. Currently investigated drugs in COVID-19 grouped according to their clinical use

Figure 2. Skin manifestations similar to those in other viral infections. A. Urticaria (23), B. Morbilliform maculopapular exanthem (24), C. Vesiculopapular (chickenpox-like) exanthem (26), D. Intertriginous purpuric rash (27)

Figure 3. Skin manifestations associated with thrombovascular events and vascular pathologies. A. Transient unilateral livedo reticularis (erythema ab igne) (31), B. COVID-19-induced chilblains (32), C. Acro-ischemia with cyanosis, skin bulla, and dry gangrene in critically ill patient (35)

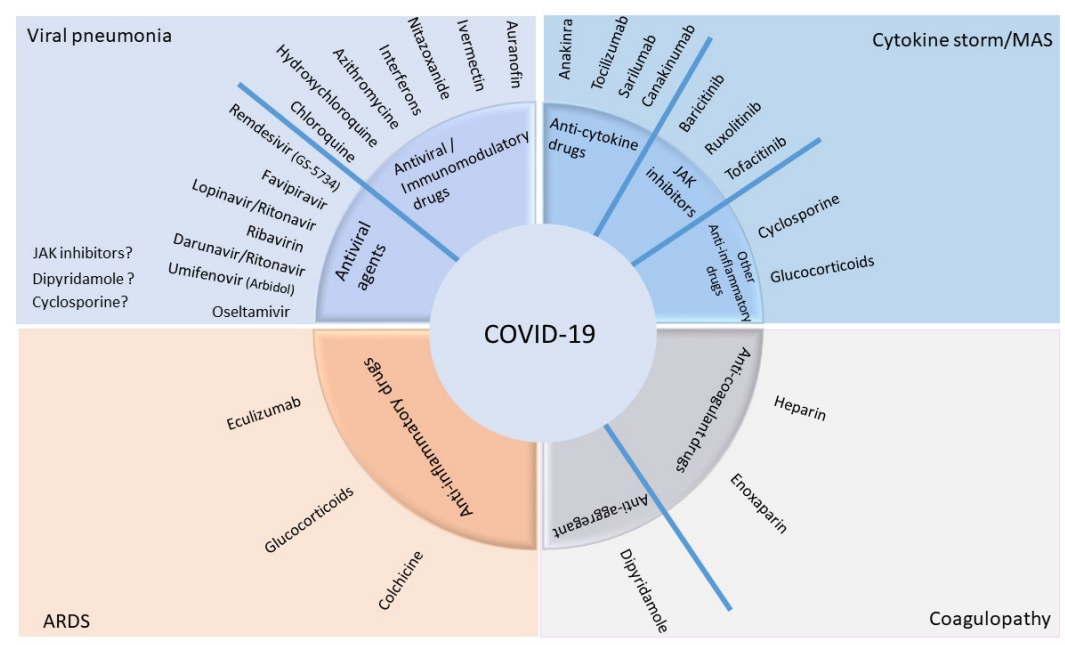



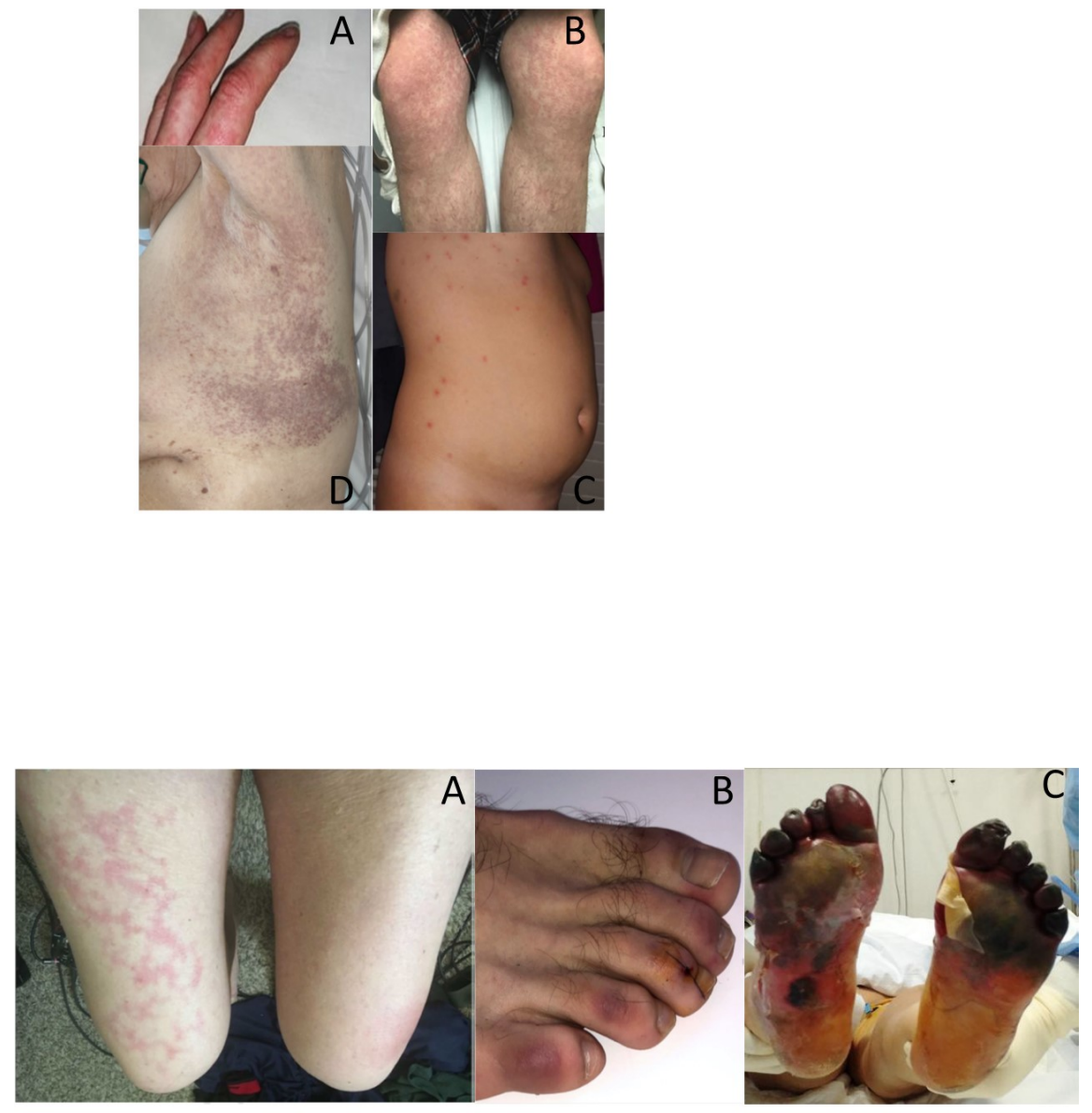